\title{
Water mass characteristics and their temporal changes in a biological hotspot in the southern Chukchi Sea
}

\author{
Shigeto Nishino $^{1}$, Takashi Kikuchi ${ }^{1}$, Amane Fujiwara ${ }^{1}$, Toru Hirawake ${ }^{2}$, and Michio Aoyama ${ }^{3,4}$ \\ ${ }^{1}$ Institute of Arctic Climate and Environment Research, Japan Agency for Marine-Earth Science \\ and Technology, Yokosuka, Japan \\ ${ }^{2}$ Faculty of Fisheries Sciences, Hokkaido University, Hakodate, Japan \\ ${ }^{3}$ Research and Development Center for Global Change, Japan Agency for Marine-Earth Science \\ and Technology, Yokosuka, Japan \\ ${ }^{4}$ Institute of Environmental Radioactivity, Fukushima University, Fukushima, Japan \\ Correspondence to: Shigeto Nishino (nishinos@jamstec.go.jp)
}

Received: 23 August 2015 - Published in Biogeosciences Discuss.: 6 October 2015

Revised: 6 March 2016 - Accepted: 14 March 2016 - Published: 29 April 2016

\begin{abstract}
We analysed mooring and ship-based hydrographic and biogeochemical data obtained from a Hope Valley biological hotspot in the southern Chukchi Sea. The moorings were deployed from 16 July 2012 to 19 July 2014, and data were captured during spring and autumn blooms with high chlorophyll $a$ concentrations. Turbidity increased and dissolved oxygen decreased in the bottom water at the mooring site before the autumn bloom, suggesting an accumulation of particulate organic matter and its decomposition (nutrient regeneration) at the bottom. This event may have been a trigger for the autumn bloom at this site. The bloom was maintained for 1 month in 2012 and for 2 months in 2013. The maintenance mechanism for the autumn bloom was also studied by hydrographic and biogeochemical surveys in late summer to autumn 2012 and 2013. Nutrient-rich water from the Bering Sea supplied nutrients to Hope Valley, although a reduction in nutrients occurred in 2012 by the influence of lower-nutrient water that would have remained on the Chukchi Sea shelf. In addition, nutrient regeneration at the bottom of Hope Valley could have increased nutrient concentrations and explained $60 \%$ of its nutrient content in the bottom water in the autumn of 2012. The high nutrient content with the dome-like structure of the bottom water may have maintained the high primary productivity via the vertical nutrient supply from the bottom water, which was likely caused by wind-induced mixing during the autumn bloom. Primary productivity was $0.3 \mathrm{~g} \mathrm{C} \mathrm{m}^{-2} \mathrm{~d}^{-1}$ in September 2012 and $1.6 \mathrm{~g} \mathrm{C} \mathrm{m}^{-2} \mathrm{~d}^{-1}$ in September 2013.
\end{abstract}

The lower productivity in 2012 was related to strong stratification caused by the high fraction of surface sea ice meltwater.

\section{Introduction}

The southern Chukchi Sea is one of the most biologically productive regions of the world's oceans because of nutrients supplied by northward flow of Pacific-originating water advected over the shelves from the northern Bering Sea into the Arctic Ocean (McRoy, 1993; Springer and McRoy, 1993; Hunt et al., 2013). Due to high primary productivity, a large quantity of organic matter descends to the sea floor as potential food for benthic communities, resulting in high benthic biomass (Grebmeier et al., 1988, 2006, 2015; Grebmeier, 2012). Consequently, large benthic feeders at high trophic levels, such as grey whales and walruses, also congregate there (Feder et al., 2005). Such a region of high biological activity is called a biological hotspot. Including this southern Chukchi Sea biological hotspot, the international Distributed Biological Observatory (DBO, http: //www.arctic.noaa.gov/dbo/) designated five locations in the Pacific Arctic domain, spanning the latitudinal range from the northern Bering Sea to the northern Chukchi Sea, as important locations for ecosystem monitoring. In these locations, recent biological changes are evident in the ranges of phytoplankton and zooplankton, benthic organisms, and 
fish species, as well as through loss of sea ice as habitat and platforms for marine mammals (e.g. Grebmeier et al., 2010, 2015; Grebmeier, 2012).

The Arctic has rapidly lost its summer sea ice cover over recent decades (Stroeve et al., 2007; Comiso et al., 2008; Kwok et al., 2009), which may significantly change ocean conditions and marine biological activities, including primary production, a key process sustaining the base of the marine food web. Overall, the primary productivity in the Arctic Ocean has been estimated to have increased in recent years due to an accelerated extension of the open water area and a longer ice-free season (e.g. Arrigo et al., 2008; Pabi et al., 2008). This increase particularly occurs on interior shelves near shelf slopes, where sea ice retreats are accompanied by the upwelling of nutrient-rich water that supports the increased production (Arrigo and van Dijken, 2015; Falk-Petersen et al., 2015). In contrast, outflow shelves where nutrients may already have been consumed upstream of the region exhibit either no change or a significant decline in primary productivity (Arrigo and van Dijken, 2015). The loss of sea ice and the accumulation of freshwater observed in the Canada Basin cause a deepening of the nutricline and can have negative effects on primary productivity (McLaughlin and Carmack, 2010; Nishino et al., 2011; Coupel et al., 2015). On the other hand, the recent delay in autumn freeze up in the East Siberian Sea results in the formation of a large-volume water mass by cooling and convection, and the spreading of this water into the Makarov Basin causes shoaling of the nutricline and may increase primary productivity (Nishino et al., 2013). The steepest trend of increasing primary productivity was found in the eastern (Eurasian) Arctic during the period 2003-2015 (Frey et al., 2015). Thus, the responses of primary production to sea ice loss are quite different between regions and their biogeochemical processes remain unclear.

In the Chukchi Sea, satellite data suggest an increase in primary productivity associated with the reduced sea ice extent and a longer phytoplankton growing season (Arrigo et al., 2008; Pabi et al., 2008; Arrigo and van Dijken, 2015). However, seasonal field measurements in the Chukchi Sea during the ice-free season in summer to autumn indicate a substantial decrease in recent primary productivity compared to estimates in the 1980s (Lee et al., 2007, 2013). Yun et al. (2016) speculated that a plausible reason for the recent low primary productivity in the Chukchi Sea could be the decreased concentrations of nutrients and chlorophyll $a$ $(\mathrm{Chl} a)$. It should be noted that satellite observations remain uncertain because of the limitations of assessing the productivity beneath the sea surface. For example, a subsurface Chl $a$ maximum layer could contribute to productivity if light levels are high enough and nutrients are available (Arrigo et al., 2011; Brown et al., 2015). On the other hand, samplings in summer and autumn for in situ measurements of primary productivity can bias the results unless one evaluates the maximum productivity that occurs in late spring and in early summer as sea ice retreats. In situ measurements may also reflect the large annual variation related to spatial and temporal changes in biogeochemical processes (Lee et al., 2007). Therefore, long-term monitoring using moorings with chemical and biological sensors is necessary along with shipbased hydrographic and biogeochemical surveys to better understand the responses of primary production and the associated marine ecosystem to ongoing environmental changes in the Chukchi Sea. The southern Chukchi Sea is a suitable location for such long-term monitoring because the site is one of the most biologically productive regions and thus is in a state of significant transition, with not only environmental but also potentially economic and social consequences.

The recent loss of Arctic sea ice may also induce a second bloom in autumn (autumn bloom) because the delayed freeze-up and increased exposure of the sea surface to wind stress cause significant wind-driven vertical mixing and upward supply of nutrients, resulting in increased phytoplankton biomass. Ardyna et al. (2014) used satellite data to show that the frequency and area of autumn blooms have increased recently throughout the Arctic. Nishino et al. (2015) reported an autumn bloom during strong wind events in the northern Chukchi Sea based on observational evidence. The increase in biomass during the autumn bloom could accompany changes in phytoplankton and zooplankton communities and may impact higher trophic levels in the ecosystem (Matsuno et al., 2015; Yokoi et al., 2016). However, the fate of the autumn bloom (e.g. when it begins, the trigger, how long it continues, and the mechanism maintaining it) is unclear. Seasonal monitoring of phytoplankton biomass and water mass characteristics may provide answers to such questions.

Here, we analysed mooring and ship-based data obtained from a biological hotspot in the southern Chukchi Sea to understand the water mass characteristics (and temporal changes thereof) that influence phytoplankton biomass and productivity. Mooring data, including temperature $(T)$, salinity $(S)$, dissolved oxygen (DO), Chl $a$, and turbidity near the bottom of the biological hotspot in the southern Chukchi Sea were collected from July 2012 to July 2014 for the first time. The data were used to examine changes in water mass characteristics and phytoplankton biomass associated with spring and autumn blooms in this biological hotspot. Hydrographic and biogeochemical surveys (conductivitytemperature-depth (CTD) and water sampling) were conducted across the biological hotspot during late summer to autumn 2012 and 2013. We focused on the biogeochemical parameters, e.g. light transmission, total alkalinity, DO, nutrients, Chl $a$, and primary productivity, to study the biogeochemical processes that maintain the biological hotspot until late summer and autumn, and their differences between the 2 years. The effect of sea ice meltwater on primary productivity is also discussed in association with stratification of the water column. 
Table 1. Mooring configurations.

\begin{tabular}{lllllll}
\hline Mooring & Latitude & Longitude & $\begin{array}{l}\text { Bottom } \\
\text { depth }\end{array}$ & $\begin{array}{l}\text { Sensor } \\
\text { depth }\end{array}$ & Parameters & Period \\
\hline SCH-12 & $67^{\circ} 42.18^{\prime} \mathrm{N}$ & $168^{\circ} 50.01^{\prime} \mathrm{W}$ & $52 \mathrm{~m}$ & $45 \mathrm{~m}$ & $T, S$, DO, Chl $a$, turbidity & 16 July 2012-2 October 2012 \\
SCH-12-2 & $68^{\circ} 02.00^{\prime} \mathrm{N}$ & $168^{\circ} 50.03^{\prime} \mathrm{W}$ & $59 \mathrm{~m}$ & $52 \mathrm{~m}$ & $T, S, \mathrm{DO}, \mathrm{Chl} a$, turbidity & 3 October 2012-20 July 2013 \\
SCH-13 & $68^{\circ} 02.00^{\prime} \mathrm{N}$ & $168^{\circ} 50.03^{\prime} \mathrm{W}$ & $60 \mathrm{~m}$ & $53 \mathrm{~m}$ & $T, S, \mathrm{DO}, \mathrm{Chl} a$, turbidity & 20 July 2013-19 July 2014 \\
\hline
\end{tabular}

Notes: $T, S$, DO, and Chl $a$ denote temperature, salinity, dissolved oxygen, and chlorophyll $a$, respectively.

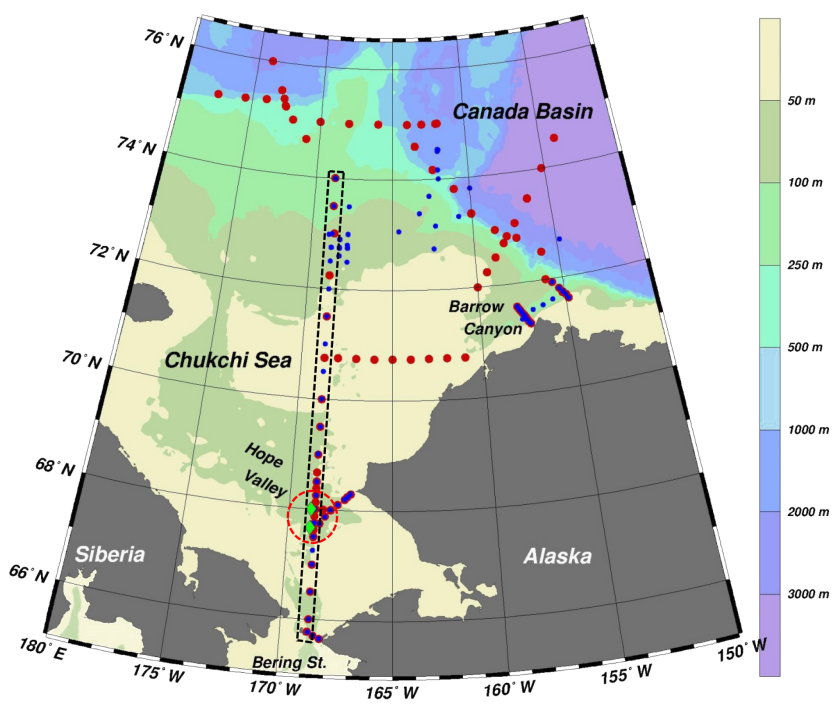

Figure 1. Map showing the bathymetric features of the study area and the hydrographic stations for the R/V Mirai cruises in 2012 (red dots) and 2013 (blue dots). Green diamonds represent the SCH-12 (southern site) and SCH-12-2/SCH-13 (northern site) mooring sites listed in Table 1. Data from the stations enclosed by black dotted lines were used for the illustrations of vertical sections shown in Figs. 5-7. The area enclosed by the red dotted circle is the southern Chukchi Sea biological hotspot, where the moorings were installed and detailed hydrographic surveys were conducted.

\section{Data and methods}

\subsection{Mooring data}

We deployed and recovered three temporally sequenced moorings (named SCH-12, SCH-12-2, and SCH-13; Table 1) from 16 July 2012 to 19 July 2014 to acquire $T, S$, DO, Chl $a$, and turbidity time series near the bottom of a biological hotspot located in Hope Valley of the southern Chukchi Sea (Fig. 1). A MicroCAT C-T Recorder, SBE 37-SM (SeaBird Electronics, Bellevue, WA, USA) was used to acquire the $T$ and $S$ data. Maximum drift in the sensors over 1 year were $0.002{ }^{\circ} \mathrm{C}$ for temperature and 0.01 for salinity in pre- and post-calibration comparisons. The AROW-USB phosphorescent DO sensor was used (JFE Advantech Co., Ltd., Kobe, Japan). The sensor was calibrated using oxygensaturated and anoxic water to determine the linear relation- ship between them with $\pm 2 \%$ accuracy. Fluorescence and backscatter were measured to obtain the Chl $a$ and turbidity data, respectively, using ACLW-USB sensors (JFE Advantech). Chl $a$ nonlinearity between 0 and $200 \mathrm{mg} \mathrm{m}^{-3}$ was $\pm 1 \%$. The turbidity sensor was calibrated by the manufacturer using Formazin standard solutions, and the results were expressed in Formazin Turbidity Units (FTUs). The accuracy of the turbidity sensor was \pm 0.3 FTU or $\pm 2 \%$. The data were recorded every hour and were smoothed using a running $24 \mathrm{~h}$ mean after removing spike noise. The DO value obtained on 1 September 2013 from the third mooring (SCH13) was $69 \mu \mathrm{mol} \mathrm{kg}{ }^{-1}$ higher than that from the water sample collected at the nearest location and time to the mooring data acquisition. Thus, we subtracted this excess value from the SCH-13 mooring DO data, which were collected from 20 July 2013 to 19 July 2014, for the data correction.

To analyse the mooring data, we used the definitions of water masses from previous studies. The bottom waters in the Chukchi Sea that originate from the Pacific Ocean in summer and winter are characterised by $T$ and $S$. In summer, they can be classified into three water masses: Anadyr water $\left(S>32.5, T=-1.0-1.5^{\circ} \mathrm{C}\right)$ in the west, Bering shelf water $\left(S=31.8-32.5, T=0-4{ }^{\circ} \mathrm{C}\right)$ in the centre, and Alaskan coastal water (ACW; $S<31.8, T>4{ }^{\circ} \mathrm{C}$ ) near the Alaskan coast (Coachman et al., 1975; Coachman, 1987; Grebmeier et al., 1988). As the Anadyr and Bering shelf waters are usually not distinct in the Chukchi Sea, the combined water mass is called the Bering shelf-Anadyr water (BSAW; $S \geq 31.8$, $\left.T=-1.0-4^{\circ} \mathrm{C}\right)$. In winter, the water mass called Bering winter water (BWW; $S=32.4-34.0, T \leq-1.6^{\circ} \mathrm{C}$ ) occupies the Chukchi Sea (Coachman and Barnes, 1961; Lowry et al., 2015). Occasionally, hypersaline water (HSW; $S>34.0$ with freezing temperature of seawater, $T \sim-1.8^{\circ} \mathrm{C}$ ) is formed due to brine rejection in leads and polynyas in the Chukchi Sea (Weingartner et al., 1998).

\subsection{Ship-based data}

Ship-based hydrographic and biogeochemical surveys were conducted in the Chukchi Sea and Canada Basin from 13 September to 4 October 2012 and from 31 August to 4 October 2013 on board the R/V Mirai of the Japan Agency for Marine-Earth Science and Technology, JAMSTEC (Fig. 1). Detailed descriptions of the 2012 and 2013 R/V Mirai 
Table 2. R/V Mirai survey periods.

\begin{tabular}{ll}
\hline Year & Period \\
\hline 2004 & 3 September-9 October \\
2008 & 28 August-6 October \\
2010 & 4 September-13 October \\
2012 & 13 September-4 October \\
2013 & 31 August-4 October \\
\hline
\end{tabular}

cruises, including the above-mentioned moorings, are provided in the cruise reports (Kikuchi, 2012 and Nishino, 2013, respectively), and the data will be open to the public via the JAMSTEC website (http://www.godac.jamstec.go.jp/ darwin/e). We also used data obtained from cruises of the R/V Mirai in 2004, 2008, and 2010, which were downloaded from the JAMSTEC website, to compare to the data from 2012 and 2013. The R/V Mirai survey periods for the area north of the Bering Strait in each year are listed in Table 2.

A CTD (SBE 9plus; Sea-Bird Electronics) and a carousel water-sampling system with 36 Niskin bottles $(12 \mathrm{~L})$ were used to collect data. In addition, DO, light transmission, fluorescence, and photosynthetically active radiation sensors were attached to the CTD system. Seawater samples were collected to measures $S$, DO, total alkalinity, nutrients (nitrate, nitrite, phosphate, silicate, and ammonium), Chl $a$, primary productivity, and other chemical and biological parameters.

Bottle $S$ samples were analysed following the Global Ocean Ship-based Hydrographic Investigations Program (GO-SHIP) Repeat Hydrography Manual using a Guildline Autosal salinometer and International Association for the Physical Sciences of the Oceans standard seawater as reference material (Kawano, 2010). Precision values of the salinity measurements in 2012 and 2013 were 0.0060 and 0.0068 , respectively, for shallow-water samples $(\leq 200 \mathrm{~m})$, and 0.0003 and 0.0002 , respectively, for deep-water samples (>200 m).

DO in the samples was measured by Winkler titration following World Ocean Circulation Experiment Hydrographic Program operations and methods (Dickson, 1996). Precision values for the 2012 and 2013 DO measurements were both $0.12 \mu \mathrm{mol} \mathrm{kg}{ }^{-1}$.

Total alkalinity in the samples was measured using a spectrophotometric system and the scheme reported by Yao and Byrne (1998). The total alkalinity values were calibrated against certified reference material provided by Dickson (Scripps Institute of Oceanography, San Diego, CA, USA). The precision for the 2012 and 2013 total alkalinity measurements was 0.57 and $0.80 \mu \mathrm{mol} \mathrm{kg}{ }^{-1}$, respectively.

Nutrient samples were analysed according to the GOSHIP Repeat Hydrography Manual (Hydes et al., 2010) using reference materials for nutrients in seawater (Aoyama and Hydes, 2010; Sato et al., 2010). The 2012 and 2013 pre-
Table 3. End-member values used in this study.

\begin{tabular}{lcc}
\hline & Salinity & $\begin{array}{c}\text { Potential alkalinity } \\
\left(\mu \mathrm{mol} \mathrm{kg}^{-1}\right)\end{array}$ \\
\hline SIM (sea ice meltwater) & 4 & 263 \\
$\begin{array}{l}\text { MW (meteoric water }= \\
\text { river runoff + precipitation) }\end{array}$ & 0 & 1620 \\
SE (saline end-member) & 32.5 & 2223 \\
\hline
\end{tabular}

cision values, expressed as coefficients of variation $(\mathrm{CVs})$, were 0.12 and $0.11 \%$ for nitrate, 0.21 and $0.19 \%$ for nitrite, 0.19 and $0.11 \%$ for phosphate, 0.11 and $0.16 \%$ for silicate, and 0.34 and $0.30 \%$ for ammonium, respectively.

Chl $a$ was measured in seawater samples using a fluorometric non-acidification method (Welschmeyer, 1994) and a Turner Design fluorometer (10-AU-005; Sunnyvale, CA, USA). The precision of the $2013 \mathrm{Chl} a$ measurements (CV) was $5.3 \%$. Precision was not estimated in 2012 because multiple samples were not available for the estimate.

Primary phytoplankton productivity was determined using the stable ${ }^{13} \mathrm{C}$ isotope method (Hama et al., 1983). We sampled seawater from seven optical depths at 100, 38, 14, $7,4,1$, and $0.6 \%$ of surface irradiance. The seawater samples were inoculated with a $200 \mu \mathrm{M}$ labelled carbon substrate $\left(\mathrm{NaH}^{13} \mathrm{CO}_{3}\right)$ that represented $\sim 10 \%$ enrichment of the total inorganic carbon in ambient water. The samples were placed in an incubator for $24 \mathrm{~h}$. Incubator temperature was maintained with running water from the sea surface. After incubation, the water samples were filtered through glass fibre filters (Whatman GF/F, $25 \mathrm{~mm}$ in diameter; Maidstone, UK) that had been pre-combusted at $450{ }^{\circ} \mathrm{C}$ for $4 \mathrm{~h}$. The ${ }^{13} \mathrm{C}$ measurements were performed onboard using a stable-isotope analyser (ANCA-SL; SerCon Ltd., Gateway, Crewe, UK). The 2012 and 2013 primary productivity precision values (CVs) were 6.5 and $7.2 \%$, respectively.

We used the fraction of sea ice meltwater $\left(f_{\mathrm{SIM}}\right)$ calculated from the relationship between potential alkalinity (total alkalinity + nitrate - ammonium) and salinity for the water mass analysis, based on Yamamoto-Kawai et al. (2009). They assumed that each seawater sample is a mixture of three endmembers, such as sea ice meltwater (SIM), meteoric water (MW; river runoff + precipitation), and a saline end-member (SE). The fraction of each end-member component was estimated using the following mass balance equations:

$$
\begin{aligned}
& f_{\mathrm{SIM}}+f_{\mathrm{MW}}+f_{\mathrm{SE}}=1, \\
& f_{\mathrm{SIM}} S_{\mathrm{SIM}}+f_{\mathrm{MW}} S_{\mathrm{MW}}+f_{\mathrm{SE}} S_{\mathrm{SE}}=S, \\
& f_{\mathrm{SIM}} \mathrm{PA}_{\mathrm{SIM}}+f_{\mathrm{MW}} \mathrm{PA}_{\mathrm{MW}}+f_{\mathrm{SE}} \mathrm{PA} \mathrm{SE}_{\mathrm{SE}}=\mathrm{PA},
\end{aligned}
$$

where $S$ and PA are observed salinity and potential alkalinity of seawater, respectively, and $f, S$, and PA with subscripts are the fraction, salinity, and potential alkalinity, respectively, of the three SIM, MW, and SE end-members. All end-member values are listed in Table 3. An end-member 

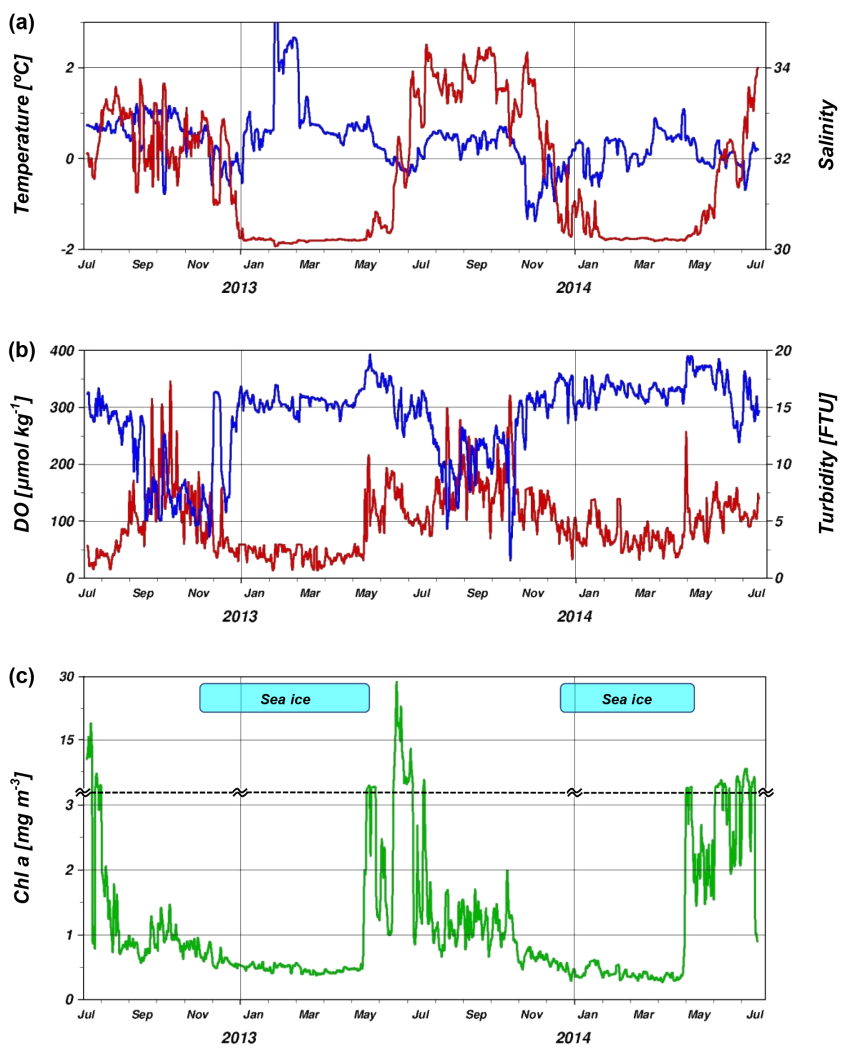

Figure 2. Time series of (a) temperature $\left({ }^{\circ} \mathrm{C}\right.$; red) and salinity (blue), (b) dissolved oxygen, DO, ( $\mu \mathrm{mol} \mathrm{kg}{ }^{-1}$; blue) and turbidity (in Formazin Turbidity Units, FTUs; red), and (c) chlorophyll $a$, $\mathrm{Chl} a,\left(\mathrm{mg} \mathrm{m}^{-3}\right.$; green). The data were obtained from the $\mathrm{SCH}-$ 12 , SCH-12-2, and SCH-13 moorings during 16 July 2012-19 July 2014. The vertical axis scale in (c) below the dotted line is exaggerated where the concentration is $<3 \mathrm{mg} \mathrm{m}^{-3}$. Periods when sea ice concentration was $>50 \%$ at the mooring site are indicated by blue bars.

$\mathrm{PA}_{\mathrm{MW}}$ value of $793 \mu \mathrm{mol} \mathrm{kg}{ }^{-1}$ was estimated by YamamotoKawai et al. (2009), but this value was obtained from samples collected in the Canada Basin, which is farther north than the study area in the southern Chukchi Sea and under an apparent larger influence of Eurasian rivers. Because the study area is rather influenced by North American rivers, we assumed the $\mathrm{PA}_{\mathrm{MW}}$ to be $1620 \mu \mathrm{mol} \mathrm{kg}{ }^{-1}$, based on the flow-weighted average of alkalinity estimated from the rivers (Cooper et al., 2008). The fraction of sea ice meltwater, $f_{\mathrm{SIM}}$, increases when seawater is influenced by sea ice melt in summer and decreases when seawater is influenced by the formation of sea ice in winter. A negative $f_{\text {SIM }}$ implies formation of sea ice, which removes freshwater from seawater and ejects brine into seawater and is dominant over sea ice melt.

\section{Results}

\subsection{Mooring data}

\subsubsection{T and $S$}

As described in Sect. 2.1, the bottom waters in the Chukchi Sea are classified into ACW, BSAW, BWW, and HSW. The $T$ and $S$ characteristics from the mooring data (Fig. 2a) indicate seasonal changes between these waters. The BSAW occupied the bottom of the mooring site during July-November 2012. In mid-October 2012, we found water fresher than the BSAW that was likely influenced by the ACW. The BSAW was replaced by the BWW in January 2013, and the HSW appeared in February 2013. Then, the BWW occupied the bottom of the mooring site again until May 2013. During July-October 2013 the BSAW was found at the bottom of the mooring site, but it was warmer and fresher compared with 2012. In November 2013, there was warm water fresher than the BSAW, and thus it was thought to be the ACW that was modified by seasonal cooling. The cooling eventually produced water with freezing temperature $\left(T \sim-1.8^{\circ} \mathrm{C}\right)$ that was present at the bottom of the mooring site during February-April 2014. The freezing temperature water was identified with the BWW except for the water in March that was fresher than the BWW. During May-July 2014, temperature increased and salinity decreased with the replacement of the BWW by the BSAW. In summary, the BSAW (BWW) was generally presented in summer and autumn (winter and spring) at the bottom of the mooring site.

\subsubsection{DO and turbidity}

DO concentration (blue line in Fig. 2b) varied in response to the change in water masses. The BWW and HSW had high DO concentrations ( $>300 \mu \mathrm{mol} \mathrm{kg}{ }^{-1}$ ) because the waters undergo cooling and convection in winter with oxygen supplied from the atmosphere. On the other hand, there was a wide range of DO concentrations in BSAW. DO concentration was high $\left(\sim 300 \mu \mathrm{mol} \mathrm{kg}^{-1}\right)$ in the beginning when the BSAW occupied the mooring site in July. Then it decreased gradually over time and had minimum values $\left(\sim 100 \mu \mathrm{mol} \mathrm{kg}{ }^{-1}\right)$ between September and November 2012 and between $\mathrm{Au}-$ gust and October 2013.

Turbidity (red line in Fig. 2b) was lowest in an annual cycle during winter and spring when the BWW or HSW occupied the site. Then it increased sharply in May 2013 and 2014, when the DO concentration also increased. In July 2012 and 2013, when the BSAW began to occupy the site, turbidity became relatively lower ( $\sim 5$ FTU or less) and subsequently reached an annual maximum (10-15 FTU) between September and November 2012 and between August and October 2013. The period of annual maximum turbidity corresponded with the period of annual minimum DO. 

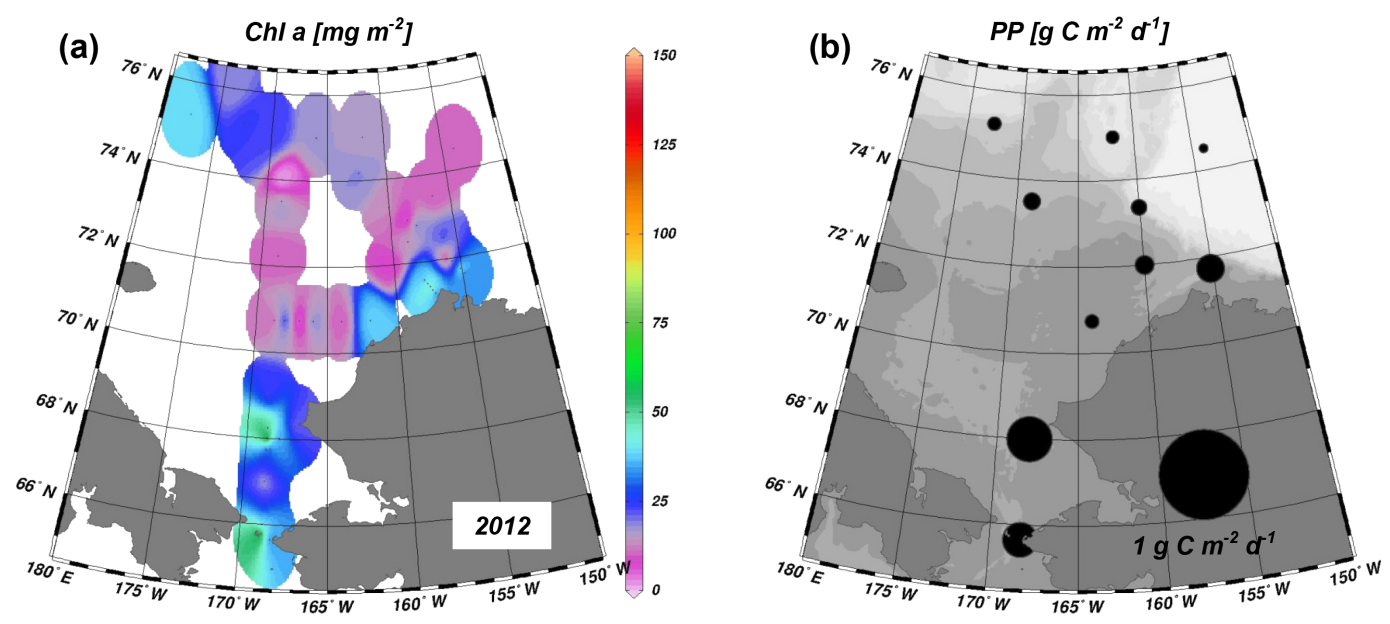

Figure 3. (a) Chlorophyll $a$ integrated over the water column $\left(\mathrm{mg} \mathrm{m}^{-2}\right)$ and (b) daily primary productivity in the water column $\left(\mathrm{g} \mathrm{C} \mathrm{m}^{-2} \mathrm{~d}^{-1}\right)$ obtained from the $2012 \mathrm{R} / \mathrm{V}$ Mirai cruise.
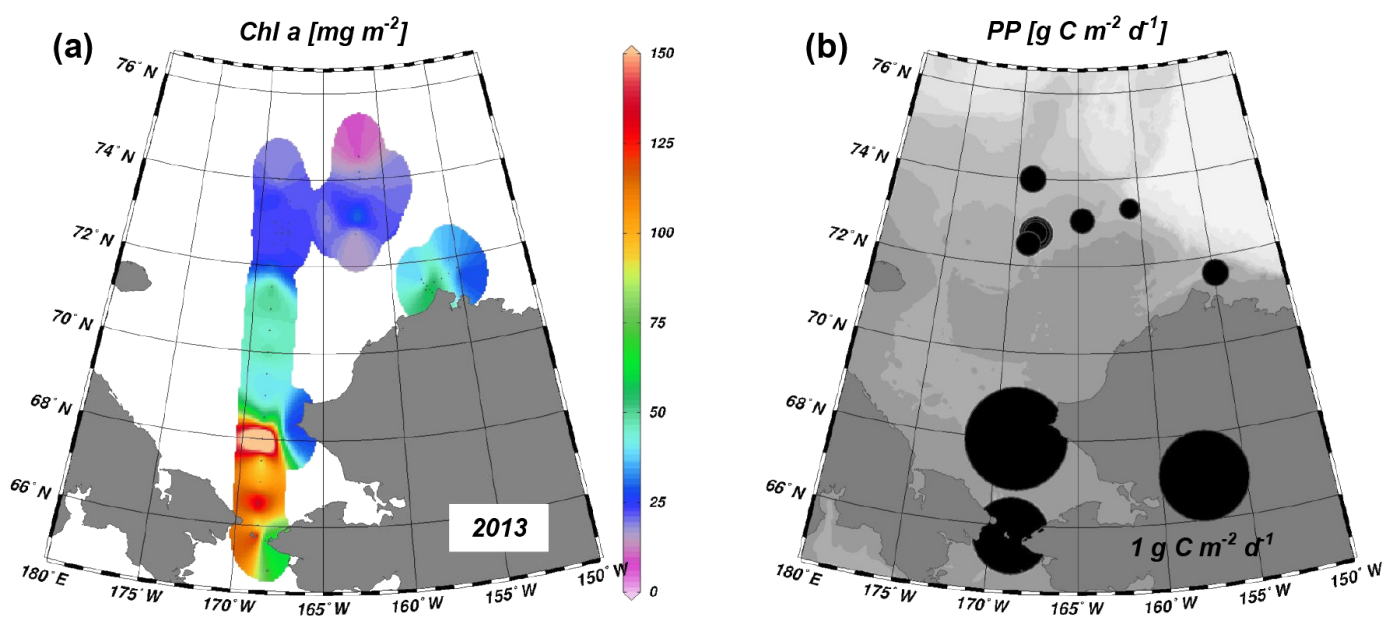

Figure 4. (a) Chlorophyll $a$ integrated over the water column $\left(\mathrm{mg} \mathrm{m}^{-2}\right)$ and (b) daily primary productivity in the water column $\left(\mathrm{g} \mathrm{C} \mathrm{m}^{-2} \mathrm{~d}^{-1}\right)$ obtained from the $2013 \mathrm{R} / \mathrm{V}$ Mirai cruise.

\subsubsection{Chl a}

Chl $a$ concentration (Fig. 2c) increased sharply in May, when sea ice still remained in the area, and the high concentration continued until July. The sharp increase in Chl $a$ in May was in synchrony with the sharp increases in DO concentration and turbidity (blue and red lines in Fig. 2b, respectively). In addition, relatively high Chl $a$ concentrations $\left(>1 \mathrm{mg} \mathrm{m}^{-3}\right.$ ) were found in September-October 2012 and August-October 2013, although the concentrations were much lower than those in late spring to early summer (MayJuly). The time series of the turbidity data showed two peaks in accordance with annual variation in Chl $a$ concentration, i.e. high turbidity in late spring and early summer and in autumn. However, turbidity was higher in autumn than in late spring and early summer, despite $\mathrm{Chl} a$ concentrations being lower in autumn.

\subsection{Ship-based data}

\subsubsection{Chl $a$ and primary productivity}

The hydrographic and biogeochemical surveys were conducted in the Chukchi Sea and the Canada Basin during September to early October 2012 and 2013, when the mooring data indicated high Chl $a$ and turbidity with low DO concentrations. The spatial distribution of Chl $a$ integrated over the water column in 2012 (Fig. 3a) showed that the quantity of Chl $a$ was relatively high in the Bering Strait, Hope Valley, and Barrow Canyon, where primary productivity in the water column was also high compared to that in the central Chukchi Sea and the Canada Basin in 2012 (Fig. 3b). The high productivity regions are thought to be the biological hotspots. The quantity of Chl $a$ in the water column in 2013 was higher everywhere compared to 2012, and the highest quantity was 

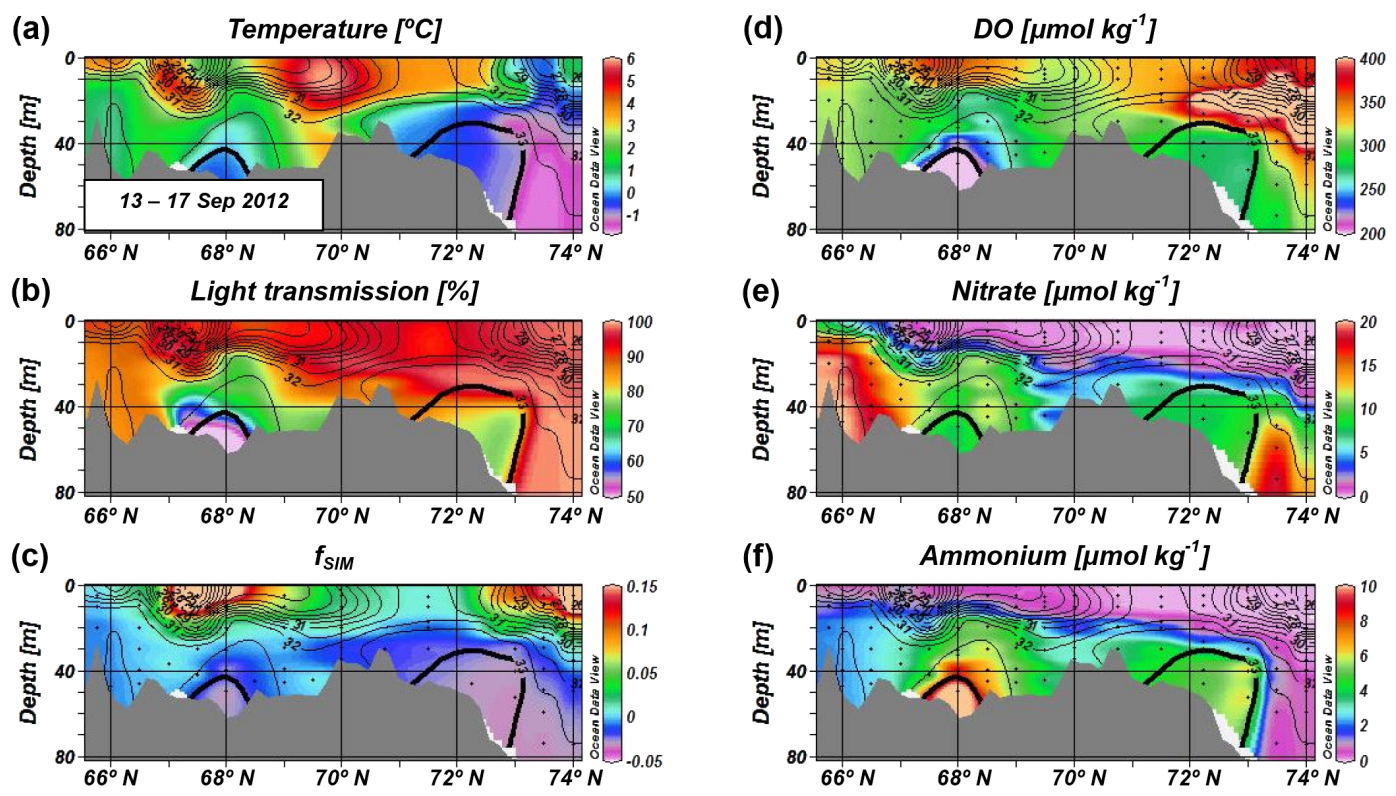

Figure 5. Vertical sections of (a) temperature $\left({ }^{\circ} \mathrm{C}\right)$, (b) light transmission (\%), (c) fraction of sea ice meltwater, (d) dissolved oxygen $(\mu \mathrm{mol} \mathrm{kg}-1)$, (e) nitrate $\left(\mu \mathrm{mol} \mathrm{kg}{ }^{-1}\right)$, and (f) ammonium $\left(\mu \mathrm{mol} \mathrm{kg} \mathrm{kg}^{-1}\right.$ ) along the $168^{\circ} 45^{\prime} \mathrm{W}$ meridian near the US-Russia border obtained during the 13-17 September 2012 R/V Mirai cruise. The water sampling level at each station is indicated by a black dot. Salinity contours are superimposed on each section with a 0.5 contour interval. The thick contour in each section indicates a salinity of 33 .

detected in Hope Valley (Fig. 4a). Similarly, primary productivity integrated over the water column was higher in 2013 throughout the entire study area (Fig. 4b), and the value was highest in Hope Valley $\left(1.6 \mathrm{~g} \mathrm{C} \mathrm{m}^{-2} \mathrm{~d}^{-1}\right)$, approximately 5 times higher than that in $2012\left(0.3 \mathrm{~g} \mathrm{C} \mathrm{m}^{-2} \mathrm{~d}^{-1}\right)$. Despite being downstream from nutrient-rich water from the Bering Sea, the algal biomass and primary productivity in Hope Valley were comparable to or higher than those in the Bering Strait during both years.

\subsubsection{Hotspot sections in 2012}

A hydrographic section was obtained from the Bering Strait to the shelf slope of the Chukchi Sea along $168^{\circ} 45^{\prime} \mathrm{W}$ across the biological hotspot of the southern Chukchi Sea at $\sim 68^{\circ} \mathrm{N}$ on $13-17$ September 2012 (Fig. 5). $T$ and $S$ (Fig. 5a) characterise the water mass distribution in this section. In the shelf area (from the Bering Strait to $72^{\circ} \mathrm{N}$ ), ACW ( $S<31.8$, $T>4^{\circ} \mathrm{C}$ ) was found at $\sim 67$ and $69-70^{\circ} \mathrm{N}$ in the upper layer $(<\sim 20 \mathrm{~m})$ and BSAW occupied the lower layer. Over the shelf slope (north of $72^{\circ} \mathrm{N}$ ), BWW with near-freezing temperature was found at $73-74^{\circ} \mathrm{N}$ below a depth of $\sim 40 \mathrm{~m}$. The saline bottom water $(S>33)$ around $72^{\circ} \mathrm{N}$ was classified as BSAW, but the water temperature was relatively low indicating that it was likely influenced by the adjacent BWW to the north. We found a dome-like structure of bottom water characterised by an uplifted isohaline (isopycnal) surface at $\sim 68^{\circ} \mathrm{N}$ with lower $T$ and higher $S$ than those of the surroundings. This bottom water at $\sim 68^{\circ} \mathrm{N}$ was also characterised by the lowest light transmission in this section
(Fig. 5b). The light transmission was relatively low in the bottom water around $72^{\circ} \mathrm{N}$, but it increased sharply in the BWW $\left(73-74^{\circ} \mathrm{N}\right)$.

We calculated $f_{\text {SIM }}$ to examine whether the water was influenced by sea ice melt or brine rejection (Fig. 5c). The surface water was influenced largely by sea ice melt $\left(f_{\mathrm{SIM}}>0\right)$, especially at $67-69^{\circ} \mathrm{N}$ and over the shelf slope. On the other hand, the bottom waters at $\sim 68$ and $72^{\circ} \mathrm{N}$ and the BWW $\left(73-74^{\circ} \mathrm{N}\right)$ were associated with brine rejection $\left(f_{\mathrm{SIM}}<0\right)$.

The DO distribution (Fig. 5d) showed a subsurface DO maximum over the shelf slope, which was almost coincident with a subsurface Chl $a$ maximum (not shown) and associated with photosynthesis in this maximum layer as described in previous studies (e.g. Codispoti et al., 2005; Martin et al., 2010). A notable feature in this section was the lowest DO in the bottom water at $\sim 68^{\circ} \mathrm{N}$. Nitrate (Fig. 5e) was depleted at the surface, except for the Bering Strait, and high concentrations $\left(\sim 20 \mu \mathrm{mol} \mathrm{kg}^{-1}\right)$ were found in the bottom water of the strait and BWW. The nitrate concentration in the bottom water at $\sim 68^{\circ} \mathrm{N}$ was relatively low $\left(\sim 7 \mu \mathrm{mol} \mathrm{kg}{ }^{-1}\right)$. Ammonium (Fig. 5f) was also depleted at the surface, and in contrast to the nitrate, the concentrations were low in the bottom water of the Bering Strait $\left(\sim 2 \mu \mathrm{mol} \mathrm{kg}{ }^{-1}\right)$ and BWW $\left(<0.5 \mu \mathrm{mol} \mathrm{kg}^{-1}\right)$ and highest in the bottom water at $\sim 68^{\circ} \mathrm{N}\left(\sim 12 \mu \mathrm{mol} \mathrm{kg}{ }^{-1}\right)$. The ammonium concentration at $\sim 68^{\circ} \mathrm{N}\left(\sim 12 \mu \mathrm{mol} \mathrm{kg}{ }^{-1}\right)$ reached $60 \%$ of the total inorganic nitrogen $(\mathrm{TIN}=$ nitrate + nitrite + ammonium $)$ concentration $\left(\sim 20 \mu \mathrm{mol} \mathrm{kg}^{-1}\right)$, and the TIN concentration was comparable to that in the bottom water of the Bering Strait. 

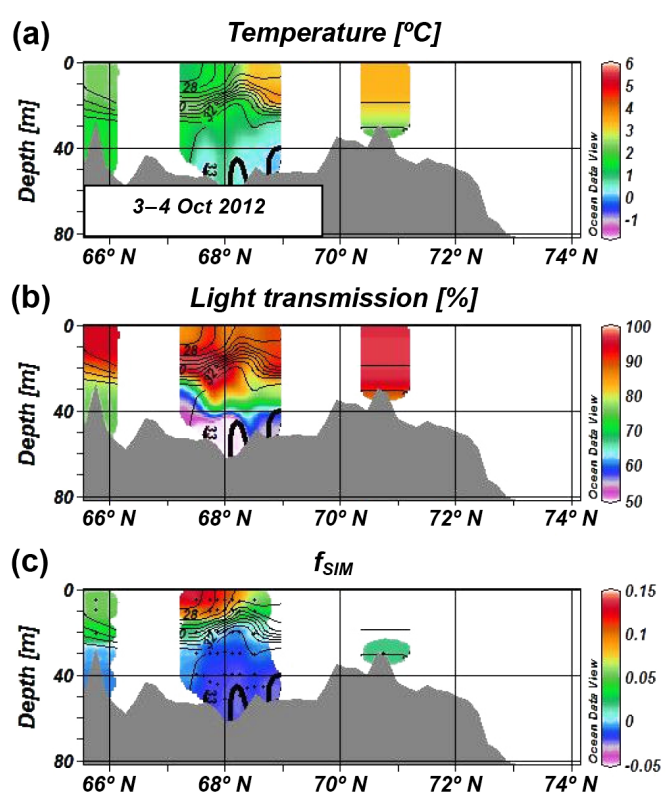
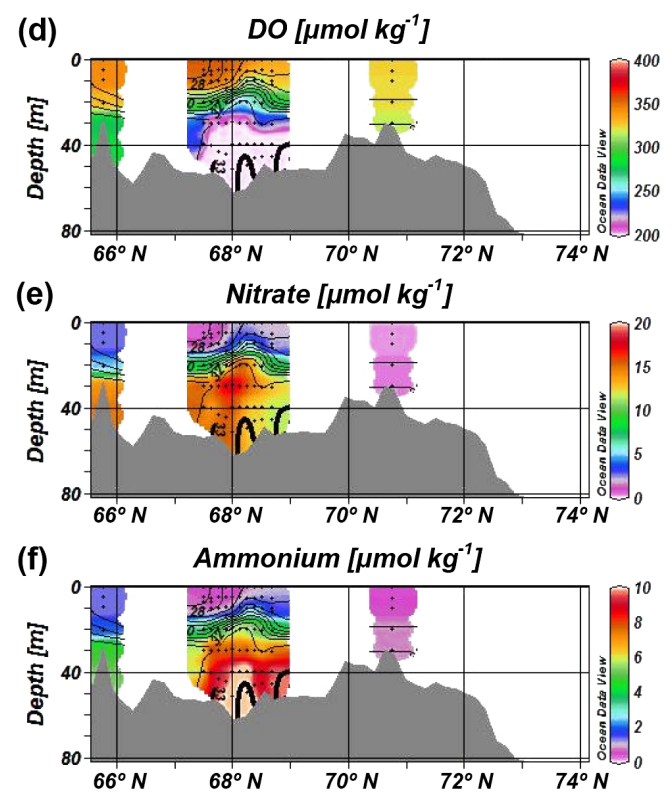

Figure 6. Vertical sections of (a) temperature $\left({ }^{\circ} \mathrm{C}\right)$, (b) light transmission (\%), (c) fraction of sea ice meltwater, (d) dissolved oxygen $(\mu \mathrm{mol} \mathrm{kg}-1)$, (e) nitrate $(\mu \mathrm{mol} \mathrm{kg}-1)$, and (f) ammonium $(\mu \mathrm{mol} \mathrm{kg}-1)$ along the $168^{\circ} 45^{\prime} \mathrm{W}$ meridian near the US-Russia border obtained during the 3-4 October 2012 R/V Mirai cruise. The water sampling level at each station is indicated by a black dot. Salinity contours are superimposed on each section with a 0.5 contour interval. The thick contour in each section indicates a salinity of 33 .
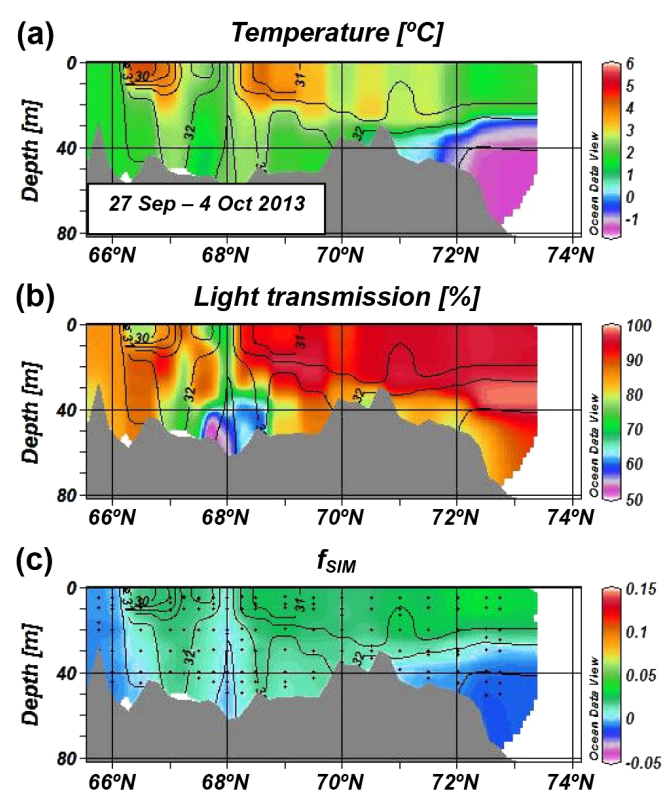
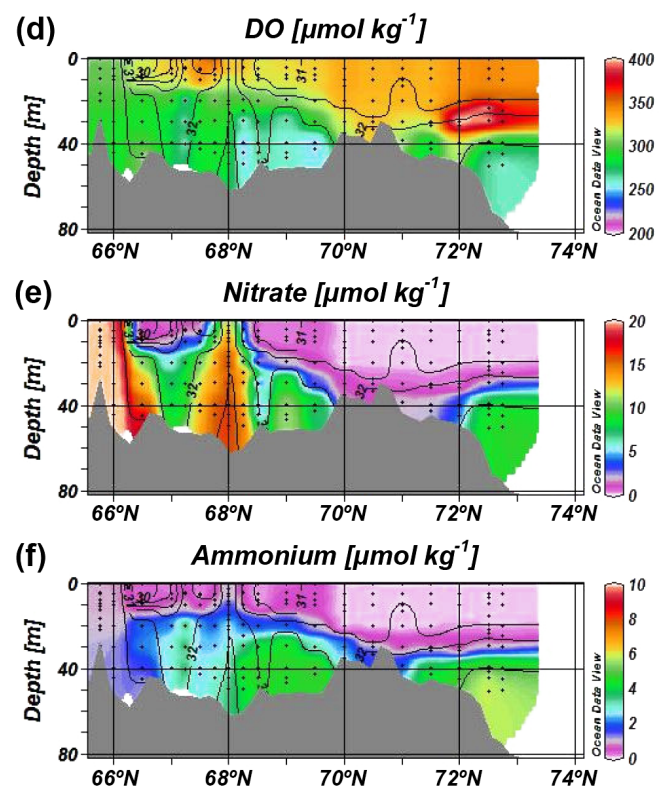

Figure 7. Vertical sections of (a) temperature $\left({ }^{\circ} \mathrm{C}\right)$, (b) light transmission (\%), (c) fraction of sea ice meltwater, (d) dissolved oxygen $(\mu \mathrm{mol} \mathrm{kg}-1)$, (e) nitrate $\left(\mu \mathrm{mol} \mathrm{kg}{ }^{-1}\right)$, and (f) ammonium $\left(\mu \mathrm{mol} \mathrm{kg}{ }^{-1}\right.$ ) along the $168^{\circ} 45^{\prime} \mathrm{W}$ meridian near the US-Russia border obtained during the 27 September-4 October 2013 R/V Mirai cruise. The water sampling level at each station is indicated by a black dot. Salinity contours are superimposed on each section with a 0.5 contour interval.

Likewise, in the bottom water at $\sim 68^{\circ} \mathrm{N}$, other nutrients, i.e. phosphate and silicate, were also comparable to those of the Bering Strait.

We revisited the biological hotspot in the southern Chukchi Sea and conducted hydrographic and biogeochem- ical surveys on 3-4 October 2012 (Fig. 6). Similar to the previous survey in mid-September, a dome-like structure of bottom water was found at $\sim 68^{\circ} \mathrm{N}$ with lower $T$, higher $S$ (Fig. 6a), and lower light transmission (Fig. 6b) than those of the surrounding water. However, bottom water $T$ was higher 
$\left(\sim 0{ }^{\circ} \mathrm{C}\right.$ vs. $\left.\sim-0.4^{\circ} \mathrm{C}\right), S$ was lower $(\sim 33$ vs. $\sim 33.2)$, and light transmission was lower $(\sim 12 \%$ vs. $\sim 30 \%)$ than the values from the previous survey. The bottom water also had a negative $f_{\text {SIM value }}(\sim-0.02$; Fig $6 \mathrm{c})$, indicating the influence of brine rejection, but its contribution was reduced from the previous survey $\left(f_{\mathrm{SIM}} \sim-0.04\right)$.

The DO concentration in this bottom water decreased from $\sim 130$ in mid-September to $\sim 110 \mu \mathrm{mol} \mathrm{kg}^{-1}$ in early October (Fig. 6d), while the nitrate concentration increased from $\sim 7$ to $\sim 16 \mu \mathrm{mol} \mathrm{kg}^{-1}$ (Fig. 6e). On the other hand, the ammonium concentration remained high $\left.(\sim 11 \mu \mathrm{mol} \mathrm{kg})^{-1}\right)$ in early October (Fig. 6f), as it was in mid-September $\left(\sim 12 \mu \mathrm{mol} \mathrm{kg}{ }^{-1}\right)$. Thus, the nitrate increase contributed to an increase in the TIN concentration $\left(\sim 28 \mu \mathrm{mol} \mathrm{kg}^{-1}\right)$ from the previous survey $\left(\sim 20 \mu \mathrm{mol} \mathrm{kg}{ }^{-1}\right)$ in the bottom water at $\sim 68^{\circ} \mathrm{N}$.

\subsubsection{Hotspot sections in 2013}

We conducted hydrographic and biogeochemical surveys from the Bering Strait to the shelf slope of the Chukchi Sea along $168^{\circ} 45^{\prime} \mathrm{W}$ from 27 September to 4 October 2013 (Fig. 7). The $T$ and $S$ distribution (Fig. 7a) indicated that BSAW was dominant in this region, except for the upper layer $(<\sim 20 \mathrm{~m})$ where ACW was found at around 67 and $69^{\circ} \mathrm{N}$. The cold water north of $72^{\circ} \mathrm{N}$ below a depth of $\sim 40 \mathrm{~m}$ was a mixture of BSAW and BWW, as was the case in 2012. Although we again found a dome-like structure of bottom water at $\sim 68^{\circ} \mathrm{N}$ with higher $S$ than the surroundings, $T$ was similar to the surroundings (Fig. 7a) and higher than that in 2012 (Figs. 5a and 6a). Light transmission there was extremely low compared to the surroundings (Fig. 7b), but higher than that in 2012 (Figs. 5b and 6b).

The $f_{\text {SIM }}$ distribution (Fig. 7c) showed little influence of sea ice melt in the upper layer compared to that in 2012 (Figs. 5c and 6c). Due to the decrease in the influence of sea ice melt, surface stratification became weaker in 2013 than in 2012. On the other hand, $f_{\text {SIM }}$ was nearly zero in the bottom waters at the Bering Strait and at $\sim 68^{\circ} \mathrm{N}$, indicating no effects of sea ice melt and brine rejection or a condition balancing these effects. Negative $f_{\text {SIM }}$ values $(\sim-0.01)$ north of $72^{\circ} \mathrm{N}$ below a depth of $\sim 40 \mathrm{~m}$ were consistent with water that had a component of BWW, which had undergone brine rejection.

In 2013 , the bottom water at $\sim 68^{\circ} \mathrm{N}$ was characterised by higher $S$ (Fig. 7a) and lower light transmission (Fig. 7b) than the surroundings; however, DO there was almost the same as that of the surroundings (Fig. 7d) and higher than that in 2012 (Figs. 5d and 6d). Nitrate (Fig. 7e) was almost depleted at the surface, except for the Bering Strait and $\sim 68^{\circ} \mathrm{N}$. In the Bering Strait, the nitrate concentration was more than $20 \mu \mathrm{mol} \mathrm{kg}{ }^{-1}$ from the surface to the bottom. Furthermore, a chimney of higher nitrate concentrations (14$17 \mu \mathrm{mol} \mathrm{kg}^{-1}$ ) than the surroundings was found at $\sim 68^{\circ} \mathrm{N}$. The bottom water concentration there $\left(68^{\circ} \mathrm{N}\right)$ was higher (a)

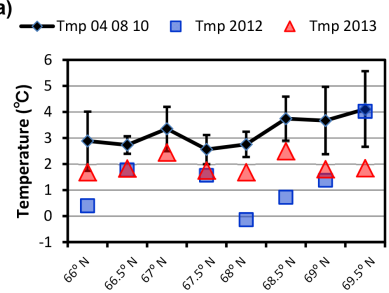

(d)

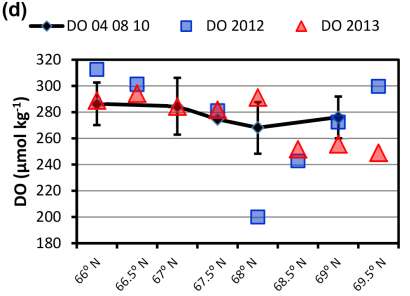

(b)

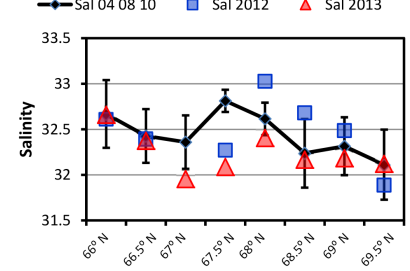

(e)

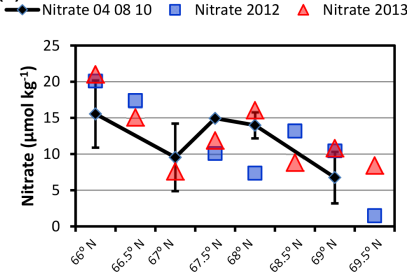

(c)

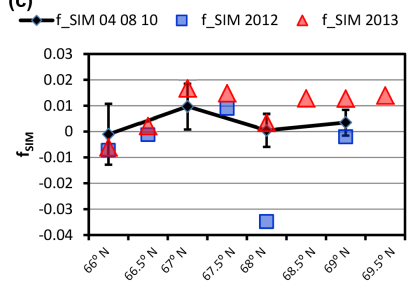

(f)

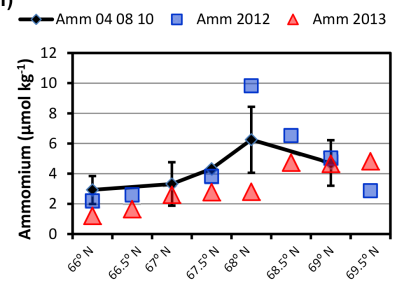

Figure 8. Plots of (a) temperature $\left({ }^{\circ} \mathrm{C}\right)$, (b) salinity, (c) fraction of sea ice meltwater, (d) dissolved oxygen $\left(\mu \mathrm{mol} \mathrm{kg}{ }^{-1}\right)$, (e) nitrate $(\mu \mathrm{mol} \mathrm{kg}-1)$, and (f) ammonium $\left(\mu \mathrm{mol} \mathrm{kg} \mathrm{k}^{-1}\right.$ ) at a depth of $40 \mathrm{~m}$ along the $168^{\circ} 45^{\prime} \mathrm{W}$ meridian near the US-Russia border with a $0.5^{\circ}$ latitudinal interval. Line plots depict the mean values of late summer to autumn 2004, 2008, and 2010 R/V Mirai data with standard error bars. Squares and triangles show the data obtained from the 13-17 September 2012 and 27 September-4 October 2013 R/V Mirai cruises, respectively.

than that in mid-September 2012 (Fig. 5e) and comparable to that in early October 2012 (Fig. 6e). Ammonium (Fig. 7f) was also almost depleted at the surface, but the concentration at $68^{\circ} \mathrm{N}$ reached $1.7 \mu \mathrm{mol} \mathrm{\textrm {kg } ^ { - 1 }}$. The bottom water concentration there $\left(68^{\circ} \mathrm{N}\right)$ was $\sim 3 \mu \mathrm{mol} \mathrm{kg}-1$ and was markedly lower than that in 2012 (Figs. 5f and 6f).

\subsubsection{Hotspot bottom water in the previous surveys}

Hydrographic and biogeochemical surveys were also conducted in the Chukchi Sea along $168^{\circ} 45^{\prime} \mathrm{W}$ across the biological hotspot at $\sim 68^{\circ} \mathrm{N}$ in late summer to autumn 2004 , 2008, and 2010 (Table 2). To examine the general features of the bottom water around $68^{\circ} \mathrm{N}$, we plotted the water characteristics meridionally at a depth of $40 \mathrm{~m}$ (Fig. 8), which is the deepest depth at which data were available at every latitude, with a $0.5^{\circ}$ interval for 2012,2013 , and for the average of the above-mentioned 3 years between the Bering Strait $\left(\sim 66^{\circ} \mathrm{N}\right)$ and the northern end of Hope Valley $\left(\sim 70^{\circ} \mathrm{N}\right.$; see Fig. 1). Although $T$ showed the lowest value among the surrounding waters at $68^{\circ} \mathrm{N}$ in 2012 (blue squares in Fig. 8a), 


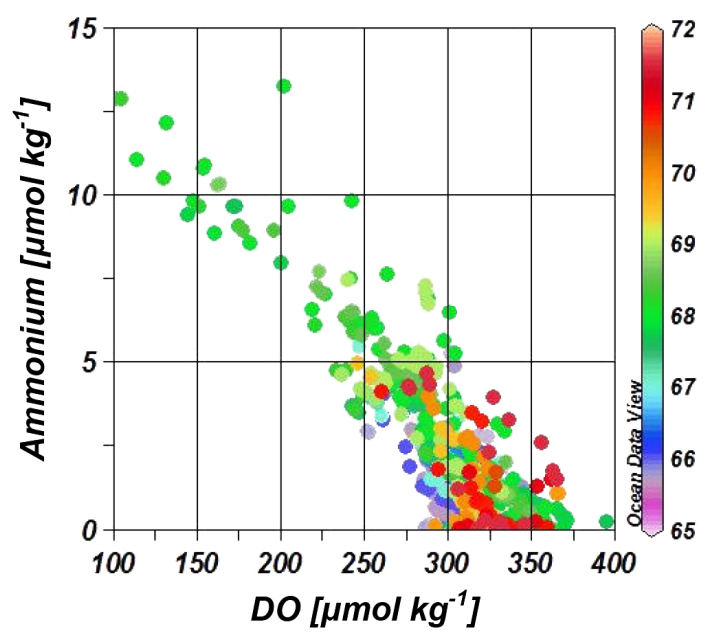

Figure 9. Diagram of dissolved oxygen $(\mu \mathrm{mol} \mathrm{kg}-1)$ and ammonium $\left(\mu \mathrm{mol} \mathrm{kg}{ }^{-1}\right)$ in the southern Chukchi Sea $\left(65-72^{\circ} \mathrm{N}\right.$, $168^{\circ} 45^{\prime} \mathrm{W}$ ). Colour indicates latitude. Data were obtained from the late summer to autumn 2004, 2008, 2010, 2012, and 2013 R/V Mirai cruises.

it did not show such significantly low values in 2013 (red triangles) and in the average of the 3 years (black dots). However, $S$ had higher values at 67.5 and $68^{\circ} \mathrm{N}$ than in the surroundings in the average (black dots in Fig. 8b), as well as higher values at $68^{\circ} \mathrm{N}$ than in the surroundings in 2012 (blue squares) and 2013 (red triangles). This indicates that the dome-like structure of the bottom water at $\sim 68^{\circ} \mathrm{N}$ with higher $S$ than the surroundings was a robust feature of the biological hotspot in the southern Chukchi Sea. The significantly low $T$ and high $S$ at $68^{\circ} \mathrm{N}$ in 2012 were accompanied by extremely low $f_{\text {SIM }}$ there compared to the surroundings in 2012 (blue squares in Fig. 8c). There was no such $f_{\text {SIM }}$ minimum feature at $68^{\circ} \mathrm{N}$ in 2013 (red triangles) or in other years (black dots).

DO was lowest among the surrounding waters at $68^{\circ} \mathrm{N}$ in 2012 (blue squares in Fig. 8d). It also showed a minimum at $68^{\circ} \mathrm{N}$ in the average (black dots), but the value there was not significantly low compared to the surroundings. A minimum at $68^{\circ} \mathrm{N}$ was not found in 2013 (red triangles). Similar to $S$, nitrate had higher values at 67.5 and $68^{\circ} \mathrm{N}$ than the surroundings in the average (black dots in Fig. 8e), as well as its maximum feature at $68^{\circ} \mathrm{N}$ in 2013 (red triangles). However, such a nitrate maximum at $68^{\circ} \mathrm{N}$ was not found in 2012 (blue squares), and the value there in 2012 was significantly low. Ammonium had higher values at $68^{\circ} \mathrm{N}$ than in the surroundings in the average (black dots in Fig. 8f) and in 2012 (blue squares), with a significantly high value in 2012, but such an ammonium maximum at $68^{\circ} \mathrm{N}$ was not found in 2013 (red triangles). In general, the ammonium distribution was inversely related to the oxygen distribution (Fig. 9), that is, as ammonium increased with latitude, DO decreased, and vice versa (Fig. 8d and f).

\section{Discussion}

\subsection{Spring and autumn blooms}

The Chl $a$ mooring data captured phytoplankton blooms, as indicated by the high $\mathrm{Chl} a$ concentrations in spring to early summer and in autumn (Fig. 2c). The first bloom in May was likely a spring bloom including a bloom of ice algae. At the onset of the spring bloom in May, both the DO concentration and the turbidity increased sharply (blue and red lines in Fig. 2b, respectively), which is consistent with the oxygen production accompanying phytoplankton photosynthetic activity and the resultant increase in phytoplankton particles.

The second bloom ( $\mathrm{Chl} a>1 \mathrm{mg} \mathrm{m}^{-3}$ ), which occurred in September-October 2012 and August-October 2013, was an autumn bloom. Before the autumn bloom, the DO concentration decreased and the turbidity increased from the end of July to the beginning of August in 2012 and 2013. The annual DO minimum and turbidity maximum occurred during the bloom. The high turbidity in autumn suggests that the turbid water contained not only phytoplankton particles but also other biogenic and lithogenic particles. The DO minimum in this period suggests decomposition of organic matter that was transported to the bottom with the particles, the amounts of which were largest in autumn in the annual cycle. This point is discussed further below.

\subsection{Autumn bloom and biogeochemical processes}

The above-mentioned mooring data revealed two novel results regarding the annual cycle of water characteristics related to the autumn bloom. A large decrease in bottom water DO occurred just before the autumn bloom but not during the spring bloom (Fig. $2 b$ and c). The decrease in DO was accompanied by an increase in bottom water turbidity, and DO (turbidity) had minimum (maximum) values during the autumn bloom. Yamada et al. (2015) observed that the concentrations of particles and particulate organic matter (POM) are extremely high at the bottom of Hope Valley in autumn, suggesting that particles including POM accumulate at the bottom there in autumn with an increase in turbidity and decrease in oxygen used to decompose accumulated POM. One conceivable source of such particles is an upstream region of northward currents that transport the BSAW through the Bering Strait (e.g. Grebmeier, 2012; Mathis et al., 2014; Grebmeier et al., 2015). This is consistent with the finding that the surface sediment along the BSAW pathway has a high amount of total organic carbon, including a large quantity of marine organic matter (phytoplankton and marine organism detritus) available to benthic populations (Grebmeier et al., 1988, 2006). The ACW could also carry Yukon River sediments (McManus et al., 1969). However, such terrestrial inputs would be difficult for use in biological processes (Grebmeier et al., 1988, 2006). Moran et al. (2005) suggested that part of the production is exported 
laterally and off the Chukchi Sea shelf during the most productive season. Therefore, in addition to export production, lateral transport of organic particles is important for oxygen consumption by sediment communities, particularly during the autumn bloom season.

The DO concentration at the bottom of the mooring site in the southern Chukchi Sea did not decrease significantly during the spring bloom or soon after the bloom. However, oxygen was largely consumed (in June) on the bottom south of St. Lawrence Island in the Bering Sea just after Chl $a$ concentrations peaked in the water column (May-June) with a time lag of days to weeks for organic material to become part of the surface sediment (Cooper et al., 2002). In general, significant correlations are observed between spatial patterns of the standing stock of Chl $a$ in the water column and the oxygen consumption of the underlying sediment community in the Bering and Chukchi Sea shelves (Grebmeier et al., 2006; Grebmeier, 2012). However, lateral transport of organic particles along northward currents of the BSAW in the southern Chukchi Sea may be important for oxygen consumption by the sediment community. The minimum levels of oxygen at the bottom during the autumn bloom in an annual cycle would not be due to a local spring phytoplankton bloom but rather would result from POM decomposition including allochthonous organic particles that accumulate in the Hope Valley topographic depression.

The mooring data in this study further suggest that the onset of particle accumulation and POM decomposition at the bottom of Hope Valley occurred from the end of July to the beginning of August in 2012 and 2013, when turbidity increased and the DO concentration decreased with time (Fig. 2b). However, Chl a concentrations decreased during this period (Fig. 2c). The increase in Chl $a$ toward the autumn bloom started in mid-September in 2012 and in mid-August in 2013. Therefore, particle accumulation and the decomposition of POM (nutrient regeneration) may have been necessary before the onset of the autumn bloom. The bloom continued for 1 month (from mid-September to mid-October) in 2012 and for 2 months (from mid-August to mid-October) in 2013. The autumn bloom has been assumed to result from autumn events, such as storms, surface cooling, and formation of sea ice (Ardyna et al., 2013, 2014). However, our data suggest that the autumn bloom is triggered by the accumulation of particles and POM decomposition that begin in summer (end of July to beginning of August), at least in the Hope Valley of the southern Chukchi Sea, and that the bloom is not an event-like phenomenon, but has a timescale of months with fluctuations that may be related to the autumn events.

\subsection{Dome-like structure in the southern Chukchi Sea}

We found a dome-like structure of dense and turbid bottom water in the biological hotspot of the southern Chukchi Sea based on hydrographic surveys during autumn blooms (Figs. 5-8). The dome-like structure would have been asso- ciated with the Hope Valley topographic depression where dense water may converge and particles likely accumulate. The bottom water characteristics there $\left(\right.$ at $\left.\sim 68^{\circ} \mathrm{N}\right)$ depended on the influences of the BSAW and BWW. The BWW, which is generally influenced by brine rejection in winter, has negative and low $f_{\text {SIM }}$ values (Yamamoto-Kawai et al., 2005). The bottom water at $\sim 68^{\circ} \mathrm{N}$ in 2012 , which was classified into BSAW from $T$ and $S$, was considered to be largely modified by mixing with the BWW because the bottom water had negative $f_{\text {SIM }}$ values comparable to those of the BWW (Figs. 5c and 6c). However, in 2013, the BSAW occupied the bottom of Hope Valley without any contribution by the BWW because the $f_{\text {SIM }}$ there was nearly zero (Fig. 7c). The large influence of the BWW in 2012 produced a prominent core of lower temperature and higher salinity (density) there compared to the surrounding area (Figs. 5a and 6a). However, the lack of a contribution by the BWW in 2013 resulted in a temperature and salinity similar to the surroundings (Fig. 7a). In other years, using the average of 2004, 2008 , and 2010 , the bottom water $f_{\text {SIM }}$ was also nearly zero at $68^{\circ} \mathrm{N}$ (Fig. 8c), suggesting no contribution by the BWW. That is, the BSAW had likely spread from the Bering Strait to the southern Chukchi Sea around $68^{\circ} \mathrm{N}$ without mixing with the BWW. This scenario is consistent with the higher $T$ and lower $S$ in the bottom water at $68^{\circ} \mathrm{N}$ on average compared to those in 2012 (Fig. 8a and b).

Whether the mechanism maintaining the dome-like structure at Hope Valley is persistent through a whole year or season is worthy of further study in the future. In winter, dense water would be produced by cooling and brine rejection, and such dense water might also converge to the Hope Valley topographic depression. The mooring data captured dense HSW ( $S>34.0, T \sim-1.8^{\circ} \mathrm{C}$; Weingartner et al., 1998) in February 2013 (Fig. 2a), and it probably formed a prominent dome-like structure. In contrast to the turbid and low DO water in late summer and autumn, the water in winter and spring had low turbidity and high DO concentrations, which did not change anomalously even during a period when the HSW appeared in February 2013 (Fig. 2b).

Nutrient concentrations under the dome-like structure at Hope Valley in late summer and autumn were also controlled by the influences of the BSAW and BWW. In general, nutrient concentrations in the BSAW increase toward the south, in regions upstream of the flow (e.g. Springer and McRoy, 1993; Grebmeier et al., 2015), and nitrate concentration is $>20 \mu \mathrm{mol} \mathrm{kg}{ }^{-1}$ in the Gulf of Anadyr, where nutrient-rich Pacific waters are first advected up onto the Bering Sea shelf (Walsh et al., 1989). Similarly, the nitrate concentration in the BWW during winter was $\sim 20 \mu \mathrm{mol} \mathrm{kg}^{-1}$ because nutrients in the Bering and Chukchi shelves undergo little biological uptake during winter (Hansell et al., 1993; Cooper et al., 1997). However, if the BWW remains on the Chukchi shelf until the next summer and autumn, nutrients are supplied to the upper layer via vertical mixing and are used for biological production and/or are diluted by mixing with 
nutrient-poor water (Lowry et al., 2015; Nishino et al., 2015). As a result, this remnant BWW on the Chukchi shelf may have low nutrient concentrations. Therefore, the contribution to Hope Valley bottom water by the remnant BWW, such as in 2012, could reduce nutrient concentrations there. In fact, the nitrate concentration there $\left(68^{\circ} \mathrm{N}\right)$, where the BSAW was largely influenced by the BWW in mid-September 2012 (Fig. 5e; $\sim 7 \mu \mathrm{mol} \mathrm{kg}-1$ ), was lower than that of the bottom water identified as the BSAW without influence from the BWW in late September and early October 2013 (Fig. 7e; $\sim 16 \mu \mathrm{mol} \mathrm{kg}^{-1}$ ) and in the other years (Fig. 8e).

The revisit of the biological hotspot in the southern Chukchi Sea in 2012 indicated a nitrate increase $\left(\sim 9 \mu \mathrm{mol} \mathrm{kg}{ }^{-1}\right)$ in the bottom water from mid-September (Fig. 5e; $\sim 7 \mu \mathrm{mol} \mathrm{kg}^{-1}$ ) to early October (Fig. 6e; $\sim 16 \mu \mathrm{mol} \mathrm{kg}^{-1}$ ). This nitrate increase also would be related to the reduced BWW contribution. The bottom water $f_{\text {SIM }}$ increased from $\sim-0.04$ to -0.02 (Figs. $5 c$ and $6 c$ ), suggesting a decrease in BWW contribution. This is consistent with the increase in $T$ and decrease in $S$ in the bottom water (Figs. 5a and 6a). Furthermore, the light transmission (Figs. 5b and 6b) and DO (Figs. 5d and 6d) of the water decreased from mid-September to early October. In general, light transmission and DO are higher in the BWW than in the BSAW because of the absence of particle inputs (less turbidity) and convection accompanying the oxygen input during winter (Fig. 2b). Therefore, the decreases in light transmission and DO are consistent with a decrease in the contribution of BWW to this bottom water. Note that part of the nitrate increase might be caused by respiration. If we assume that the DO decrease from mid-September $\left(130 \mu \mathrm{mol} \mathrm{kg} \mathrm{kg}^{-1}\right)$ to early October $\left(110 \mu \mathrm{mol} \mathrm{kg}^{-1}\right)$ was fully used for respiration, the production of nitrate is estimated to be $2.3 \mu \mathrm{mol} \mathrm{kg}{ }^{-1}$ based on the Redfield ratio ( $\mathrm{N}: \mathrm{O}_{2}=16:-138$; Redfield et al., 1963). However, this nitrate increase by respiration could only explain a maximum of $25 \%$ of the observed nitrate increase $\left(9 \mu \mathrm{mol} \mathrm{kg}{ }^{-1}\right)$.

Another important process controlling nutrient concentrations was ammonium production. Except for 2013, the water at the bottom of Hope Valley in the southern Chukchi Sea $\left(68^{\circ} \mathrm{N}\right)$ had minimum DO and maximum ammonium concentrations (Fig. 8d and f, respectively). In addition, the water there had the lowest light transmission even in 2013 (Figs. 5b, 6b, and 7b), i.e. a large amount of POM accumulated at the bottom of Hope Valley and its decomposition decreased oxygen and increased ammonium concentrations as a result of nutrient regeneration. The decomposing POM consumed oxygen and produced ammonium, generating a linear relationship between DO and ammonium concentrations in the southern Chukchi Sea (Fig. 9). The TIN at the bottom of Hope Valley in the autumn of 2012 was comparable to that in the Bering Strait, which is located upstream of the nutrient-rich BSAW flow. This high TIN concentration $\left(\sim 20 \mu \mathrm{mol} \mathrm{kg}{ }^{-1}\right)$ at the bottom of Hope Val- ley was attributed to the high concentration of ammonium (Fig. 5f; $\sim 12 \mu \mathrm{mol} \mathrm{kg}^{-1}$ ), suggesting significant nutrient regeneration at the bottom, which explained $60 \%$ of the nutrient content. The ammonium there in autumn 2013 was only $\sim 3 \mu \mathrm{mol} \mathrm{kg}^{-1}$ (Fig. 7f), but this low ammonium concentration does not necessarily mean that nutrient regeneration at that time was much lower than in autumn 2012. The weak stratification in autumn 2013 may have diluted the ammonium levels via mixing with ammonium-free water in the upper layer. The nutrient regeneration would occur significantly even in autumn 2013 because turbid water was still present, suggesting the accumulation of POM.

POM was largely carried by the BSAW during the autumn of 2012 and 2013 and accumulated in the Hope Valley topographic depression. The nutrient regeneration caused by decay of POM at this site would help increase bottom water nutrient concentrations. Furthermore, the dome-like structure lifts up the isopycnal surface, and nutrients would be supplied to the surface (euphotic zone) easier than to the surroundings. For example, nitrogenous compounds are usually depleted at the sea surface, but a relatively high level of ammonium $\left(1.7 \mu \mathrm{mol} \mathrm{kg}{ }^{-1}\right)$ was found at the surface in autumn 2013 , suggesting nutrient regeneration at the bottom and vertical transport of the ammonium produced via vertical mixing (Fig. 7f). Indeed, the nutrient supply from the BSAW is important for the phytoplankton bloom during late spring and early summer, as discussed by Springer and McRoy (1993). However, the combination of nutrient regeneration at the bottom and the uplifted isopycnal surface accompanied by the dome-like structure played an important role in maintaining the high productivity of the biological hotspot in the southern Chukchi Sea at least during late summer and autumn.

\subsection{Stratification and primary productivity}

Surface stratification in the southern Chukchi Sea was stronger in 2012 than in 2013 due to the large $f_{\text {SIM }}$ in the surface water (compare Figs. 5c, 6c, and 7c). Sea ice remained until September 2012 around Wrangel Island between the Chukchi and East Siberian seas and may have resulted in the large $f_{\text {SIM }}$ in the Chukchi Sea. The stratification isolates the bottom water from the surface, but turbulent mixing associated with winds, inertial motion, and internal waves can affect heat, salt, and nutrient exchanges between the surface and bottom waters in the Chukchi Sea (e.g. Rainville and Woodgate, 2009; Kawaguchi et al., 2015; Nishino et al., 2015). Nishino et al. (2015) suggested that the wind-induced mixing during strong wind events caused a large amount of nutrient supply from the bottom water in the Chukchi Sea, resulting in an increase in primary productivity in autumn. Because stable stratification inhibits vertical mixing and vice versa, the vertical mixing that occurred in 2013 under the weak stratification condition could easily lift the bottom water to the surface. This is evident from the observed low light transmission in the surface water at $\sim 68^{\circ} \mathrm{N}$, which seemed 
to be related to mixing from the bottom (Fig. 7b). Vertical mixing could also have increased the DO of the bottom water there, as detected in the mooring data from the end of August 2013 (Fig. 2b) and in the ship-based data showing higher bottom water DO in 2013 than in 2012 (compare Figs. 5d, 6d, and 7d). Thus, the weak stratification in the southern Chukchi Sea enhanced vertical mixing to supply nutrients to the surface water, as observed in the nitrate and ammonium profiles (Fig. 7e and f), resulting in the higher algal biomass and primary productivity in 2013 than in 2012 (compare Figs. 3 and 4).

Our estimations of primary productivity at Hope Valley were 0.3 and $1.6 \mathrm{~g} \mathrm{C} \mathrm{m}^{-2} \mathrm{~d}^{-1}$ in September 2012 and 2013, respectively. The 2013 productivity was consistent with that estimated from in situ measurements during the same season from 2002 to $2004\left(1.4 \mathrm{~g} \mathrm{C} \mathrm{m}^{-2} \mathrm{~d}^{-1}\right.$; Lee et al., 2007) and in 2007 (1.6 $\mathrm{g} \mathrm{C} \mathrm{m}^{-2} \mathrm{~d}^{-1}$; Lee et al., 2013). Lee et al. (2007, 2013) and Yun et al. (2016) suggested decreases of primary productivity in the Chukchi Sea in recent years compared to that reported in the 1980s. They hypothesised that the declining trend in primary productivity was associated with changes in water masses, the transport of nutrients with phytoplankton and sediments, primary productivity in the Bering Sea, and the large seasonal, annual, and geographical variation in primary productivity in the Chukchi Sea. However, there are some uncertainties in the estimation of the primary productivity from the in situ measurements. Most of the field samplings suggesting this declining trend in primary productivity were undertaken in summer and autumn, although the core timing of highest productivity is late spring and early summer. Our results suggest an anomalous influence of sea ice meltwater in September 2012 on the reduction of primary productivity in the Chukchi Sea. Furthermore, data obtained in September 2009 indicated that high amounts of freshwater accumulated in the Chukchi Sea from Siberian coastal currents and negatively affected primary productivity (Yun et al., 2014). Such freshwater distributions, which control water column stratification, and thus primary productivity, are likely changed by wind- and buoyancy-forced currents on synoptic and seasonal timescales (Weingartner et al., 1999). Hence, synoptic and seasonal events could largely impact the estimation of in situ productivity. In addition, the decline in productivity is contrary to the results from satellite observations (e.g. Arrigo et al., 2008; Pabi et al., 2008). Thus, the trend in primary productivity currently appears equivocal, depending on temporal and spatial issues. Further temporal studies are needed to accurately determine a trend in primary productivity in this region considering the changing Arctic environments.

\section{Summary}

We analysed mooring and ship-based data obtained from a biological hotspot in the southern Chukchi Sea to elucidate water mass characteristics and their temporal changes, and how they influence local phytoplankton biomass and productivity. The mooring data indicated a seasonal change in water masses, i.e. the BSAW in summer and autumn and BWW in winter and spring. The ship-based hydrographic and biogeochemical data suggested that the BSAW was largely modified by the BWW in autumn 2012 but not during a typical autumn (2004, 2008, 2010, and 2013). As a result, a prominent core of bottom water, which was characterised by lower temperature and higher salinity (density) than the surrounding water, was detected in 2012.

The large influence of the BWW in 2012 would have reduced nutrient concentrations because nutrients in the BWW that had remained in the Chukchi Sea until summer and autumn were probably used for the spring and autumn blooms, and/or were diluted by mixing with nutrient-poor water. In contrast, nutrient regeneration at the bottom increased nutrient concentrations and explained $60 \%$ of the nutrient levels evident in mid-September 2012. This high nutrient content, which was supplied by the BSAW and nutrient regeneration in the dome-like structure of the Hope Valley bottom water, maintained high primary productivity during the autumn bloom. However, primary productivity was largely controlled by water column stratification characterised by the distribution of freshwater from sea ice meltwater and river water.

Although the mooring in this study was deployed only at the biological hotspot site in the southern Chukchi Sea, the data show a temporal change in phytoplankton biomass and related parameters for the first time. We observed spring and autumn blooms associated with high Chl $a$ concentrations. At the onset of the spring bloom, both DO and turbidity increased sharply, which is consistent with the oxygen production accompanying phytoplankton photosynthetic activity and the resultant increase in phytoplankton particles. On the other hand, before the autumn bloom, turbidity increased but DO decreased, suggesting accumulation and decomposition of POM (nutrient regeneration) on the bottom. This may have been a trigger for the autumn bloom at this site. The mooring data further suggest that the autumn bloom had a timescale of months with fluctuations that might have been related to autumn events, such as storms, surface cooling, and the formation of sea ice.

Acknowledgements. We thank the captain, officers, and crew of the R/V Mirai, which was operated by Global Ocean Development, Inc. We also thank the staff of Marine Works Japan, Ltd., for their skilful work aboard the ship and for data processing. This study was supported by the Green Network of Excellence (GRENE) Program/Arctic Climate Change Research Project and Arctic Challenge for Sustainability (ArCS) Project, which were funded by the Ministry of Education, Culture, Sports, Science and Technology of Japan (MEXT). This work was also supported by the Japan Society for the Promotion of Science, KAKENHI (S) no. 15H05712. Maps and figures were drawn using Ocean Data View software (Schlitzer, 2015). The data used to prepare this study will be released from the 
Data Research System for Whole Cruise Information in JAMSTEC (Darwin; http://www.godac.jamstec.go.jp/darwin/e).

Edited by: M. Sampei

\section{References}

Aoyama, M. and Hydes, D. J.: How do we improve the comparability of nutrient measurements?, in: Comparability of Nutrients in the World's Ocean, edited by: Aoyama, M., Dickson, A. G., Hydes, D. J., Murata, A., Oh, J. R., Roose, P., and Woodward E. M. S., Mother Tank, Tsukuba, Japan, 1-10, 2010.

Ardyna, M., Babin, M., Gosselin, M., Devred, E., Bélanger, S., Matsuoka, A., and Tremblay, J.-É.: Parameterization of vertical chlorophyll $a$ in the Arctic Ocean: impact of the subsurface chlorophyll maximum on regional, seasonal, and annual primary production estimates, Biogeosciences, 10, 4383-4404, doi:10.5194/bg-10-4383-2013, 2013.

Ardyna, M., Babin, M., Gosselin, M., Devred, E., Rainville, L., and Tremblay, J.-É.: Recent Arctic Ocean sea ice loss triggers novel fall phytoplankton blooms, Geophys. Res. Lett., 41, 6207-6212, doi:10.1002/2014GL061047, 2014.

Arrigo, K. R. and van Dijken, G. L.: Continued increases in Arctic Ocean primary production, Prog. Oceanogr., 136, 60-70, doi:10.1016/j.pocean.2015.05.002, 2015.

Arrigo, K. R., van Dijken, G. L., and Pabi, S.: Impact of a shrinking Arctic ice cover on marine primary production, Geophys. Res. Lett., 35, L19603, doi:10.1029/2008GL035028, 2008.

Arrigo, K. R., Matrai, P. A., and van Dijken, G. L.: Primary productivity in the Arctic Ocean: Impacts of complex optical properties and subsurface chlorophyll maxima on large-scale estimates, J. Geophys. Res., 116, C11022, doi:10.1029/2011JC007273, 2011.

Brown, Z. W., Lowry, K. E., Palmer, M. A., van Dijken, G. L., Mills, M. M., Pickart, R. S., and Arrigo, K. R.: Characterizing the subsurface chlorophyll $a$ maximum in the Chukchi Sea and Canada Basin, Deep-Sea Res. Pt. II, 118, 88-104, doi:10.1016/j.dsr2.2015.02.010, 2015.

Coachman, L. K.: Advection and mixing on the Bering-Chukchi Shelves, Component A, Advection and mixing of coastal water on high latitude shelves, ISHTAR 1986 Progress Report, Vol. I, Inst. Mar. Sci., Univ. Alaska, Fairbanks, 1-42, 1987.

Coachman, L. K. and Barnes, C. A.: The contribution of Bering Sea water to the Arctic Ocean, Arctic, 14, 147-161, 1961.

Coachman, L. K., Aagaard, K., and Tripp, R. B.: Bering Strait: The regional physical oceanography. Univ. of Washington Press, Seattle, 172 pp., 1975.

Codispoti, L. A., Flagg, C., Kelly, V., and Swift, J. H.: Hydrographic conditions during the 2002 SBI process experiments, DeepSea Res. Pt. II, 52, 3199-3226, doi:10.1016/j.dsr2.2005.10.007, 2005.

Comiso, J. C., Parkinson, C. L., Gersten, R., and Stock, L.: Accelerated decline in the Arctic sea ice cover, Geophys. Res. Lett., 35, L01703, doi:10.1029/2007GL031972, 2008.

Cooper, L. W., Whitledge, T. E., Grebmeier, J. M., and Weingartner, T.: The nutrient, salinity, and stable oxygen isotope composition of Bering and Chukchi Seas waters in and near the Bering Strait, J. Geophys. Res., 102, 12563-12573, 1997.
Cooper, L. W., Grebmeier, J. M., Larsen, I. L., Egorov, V. G., Theodorakis, C., Kelly, H. P., and Lovvorn, J. R.: Seasonal variation in water column processes and sedimentation of organic materials in the St. Lawrence Island polynya region, Bering Sea, Mar. Ecol.-Prog. Ser., 226, 13-26, 2002.

Cooper, L. W., McClelland, J. M., Holmes, R. M., Raymond, P. A., Gibson, J. J., Guay, C. K., and Peterson, B. J.: Flowweighted values of runoff tracers $\left(\delta^{18} \mathrm{O}, \mathrm{DOC}, \mathrm{Ba}\right.$, alkalinity) from the six largest Arctic rivers, Geophys. Res. Lett., 35, L18606, doi:10.1029/2008GL035007, 2008.

Coupel, P., Ruiz-Pino, D., Sicre, M. A., Chen, J. F., Lee, S. H., Schiffrine, N., Li, H. L., and Gascard, J. C.: The impact of freshening on phytoplankton production in the Pacific Arctic Ocean, Prog. Oceanogr., 131, 113-125, doi:10.1016/j.pocean.2014.12.003, 2015.

Dickson, A. G.: Determination of dissolved oxygen in sea water by Winkler titration, in: WOCE Operations Manual, Volume 3, Section3.1, Part 3.1.3 WHP Operations and Methods, WHP Office Report WHPO 91-1, WOCE Report No. 68/91, Nov. 1994, Revision 1, Woods Hole, Mass., 13 pp., 1996.

Falk-Petersen, S., Pavlov, V., Berge, J., Cottier, F., Kovacs, K. M., and Lydersen, C.: At the rainbow's end: high productivity fueled by upwelling along an Arctic shelf, Polar Biol., 38, 5-11, doi:10.1007/s00300-014-1482-1, 2015.

Feder, H., Jewett, S., and Blanchard, A.: Southeastern Chukchi Sea (Alaska) epibenthos, Polar Biol., 28, 402-421, 2005.

Frey, K. E., Comiso, J. C., Cooper, L. W., Gradinger, R. R., Grebmeier, J. M., and Tremblay, J.-É.: Arctic Ocean Primary Productivity, in: Arctic Report Card 2015, edited by: Jeffries, M. O., Richter-Menge, J., and Overland, J. E., NOAA, Washington, D.C., USA, 44-53, available at: www.arctic.noaa.gov/reportcard, last access: 31 December 2015.

Grebmeier, J. M.: Shifting patterns of life in the Pacific Arctic and sub-Arctic seas, Annu. Rev. Mar. Sci., 4, 63-78, doi:10.1146/annurev-marine-120710-100926, 2012.

Grebmeier, J. M., McRoy, C. P., and Feder, H. M.: Pelagic-benthic coupling on the shelf of the northern Bering and Chukchi Seas. I. Food supply source and benthic biomass, Mar. Ecol.-Prog. Ser., 48, 57-67, 1988.

Grebmeier, J. M., Cooper, L. W., Feder, H. M., and Sirenko, B. I.: Ecosystem dynamics of the Pacific-influenced Northern Bering and Chukchi Seas in the Amerasian Arctic, Prog. Oceanogr., 71, 331-361, 2006.

Grebmeier, J. M., Moore, S. E., Overland, J. E., Frey, K. E., and Gradinger, R.: Biological response to recent Pacific Arctic sea ice retreats, EOS, 91, 161-162, 2010.

Grebmeier, J. M., Bluhm, B. A., Cooper, L. W., Danielson, S. L., Arrigo, K. R., Blanchard, A. L., Clarke, J. T., Day, R. H., Frey, K. E., Gradinger, R. R., Kedra, M., Konar, B., Kuletz, K. J., Lee, S. H., Lovvorn, J. R., Norcross, B. L., and Okkonen, S. R.: Ecosystem characteristics and processes facilitating persistent macrobenthic biomass hotspots and associated benthivory in the Pacific Arctic, Prog. Oceanogr., 136, 92-114, doi:10.1016/j.pocean.2015.05.006, 2015.

Hama, T., Miyazaki, T., Ogawa, Y., Iwakuma, T., Takahashi, M., Otsuki, A., and Ichimura, S.: Measurement of photosynthetic production of a marine phytoplankton population using a stable ${ }^{13} \mathrm{C}$ isotope, Mar. Biol., 73, 31-36, 1983. 
Hansell, D. A., Whitledge, T. E., and Goering, J. J.: Patterns of nitrate utilization and new production over the Bering-Chukchi shelf, Cont. Shelf Res., 13, 601-627, 1993.

Hunt Jr., G. L., Blanchard, A. L., Boveng, P., Dalpadado, P., Drinkwater, K. F., Eisner, L., Hopcroft, R. R., Kovacs, K. M., Norcross, B. L., Renaud, P., Reigstad, M., Renner, M., Skjoldal, H. R., Whitehouse, A., and Woodgate, R. A.: The Barents and Chukchi Seas: Comparison of two Arctic shelf ecosystems, J. Marine Syst., 109-110, 43-68, doi:10.1016/j.jmarsys.2012.08.003, 2013.

Hydes, D. J., Aoyama, M., Aminot, A., Bakker, K., Becker, S., Coverly, S., Daniel, A., Dickson, A. G., Grosso, O., Kerouel, R., van Ooijen, J., Sato, K., Tanhua, T., Woodward, E. M. S., and Zhang, J. Z.: Determination of dissolved nutrients (N, $\mathrm{P}, \mathrm{Si}$ ) in seawater with high precision and inter-comparability using gas-segmented continuous flow analysers, in: The GOSHIP Repeat Hydrography Manual: A Collection of Expert Reports and Guidelines, IOCCP Report Number 14, ICPO Publication Series Number 134, edited by: Hood, E. M., Sabine, C. L., and Sloyan, B. M., UNESCO-IOC, Paris, France, available at: www.go-ship.org/HydroMan.html (last access: 25 September 2015), 2010.

Kawaguchi, Y., Nishino, S., and Inoue, J.: Fixed-point observation of mixed layer evolution in the seasonally ice-free Chukchi Sea: Turbulent mixing due to gale winds and internal gravity waves, J. Phys. Oceanogr., 45, 836-853, doi:10.1175/JPO-D-14-0149.1, 2015.

Kawano, T.: Method for salinity (conductivity ratio) measurement, in: The GO-SHIP Repeat Hydrography Manual: A Collection of Expert Reports and Guidelines, IOCCP Report Number 14, ICPO Publication Series Number 134, edited by: Hood, E. M., Sabine, C. L., and Sloyan, B. M., UNESCO-IOC, Paris, France, available at: www.go-ship.org/HydroMan.html (last access: 25 September 2015), 2010.

Kikuchi, T.: R/V Mirai Cruise Report MR12-E03. JAMSTEC, Yokosuka, Japan, available at: www.godac.jamstec.go.jp/darwin/ e (last access: 25 September 2015), 2012.

Kwok, R., Cunningham, G. F., Wensnahan, M., Zwally, H. J., and Yi, D.: Thinning and volume loss of the Arctic Ocean sea ice cover: 2003-2008, J. Geophys. Res., 114, C07005, doi:10.1029/2009JC005312, 2009.

Lee, S. H., Whitledge, T. E., and Kang, S. H.: Recent carbon and nitrogen uptake rates of phytoplankton in Bering Strait and the Chukchi Sea, Cont. Shelf Res., 27, 2231-2249, doi:10.1016/j.csr.2007.05.009, 2007.

Lee, S. H., Yun, M. S., Kim, B. K., Saitoh, S. I., Kang, C. K., Kang, S. H., and Whitledge, T. E.: Latitudinal carbon productivity in the Bering and Chukchi seas during the summer in 2007, Cont. Shelf Res., 59, 28-36, doi:10.1016/j.csr.2013.04.004, 2013.

Lowry, K. E., Pickart, R. S., Mills, M. M., Brown, Z. W., vanDijken, G. L., Bates, N. R., and Arrigo, K. R.: The influence of winter water on phytoplankton blooms in the Chukchi Sea, Deep-Sea Res. Pt. II, 118, 53-72, doi:10.1016/j.dsr2.2015.06.006, 2015.

Martin, J., Tremblay, J.-É., Gagnon, J., Tremblay, G., Lapoussiere, A., Jose, C., Poulin, M., Gosselin, M., Gratton, Y., and Michel, C.: Prevalence, structure and properties of subsurface chlorophyll maxima in Canadian Arctic waters, Mar. Ecol.-Prog. Ser., 412, 69-84, doi:10.3354/meps08666, 2010.
Mathis, J. T., Grebmeier, J. M., Hansell, D. A., Hopcroft, R. R., Kirchman, D. L., Lee, S. H., Moran, S. B., Bates, N. R., VanLaningham, S., Cross, J. N., and Cai, W.-J.: Carbon Biogeochemistry of the Western Arctic: Primary Production, Carbon Export and the Controls on Ocean Acidification, in: The Pacific Arctic region, Ecosystem Status and Trends in a Rapidly Changing Environment, edited by: Grebmeier, J. M. and Maslowski, W., Springer, Dordrecht, Netherlands, 223-268, doi:10.1007/97894-017-8863-2, 2014.

Matsuno, K., Yamaguchi, A., Nishino, S., Inoue, J., and Kikuchi, T.: Short-term changes in the mesozooplankton community and copepod gut pigment in the Chukchi Sea in autumn: reflections of a strong wind event, Biogeosciences, 12, 4005-4015, doi:10.5194/bg-12-4005-2015, 2015.

McLaughlin, F. A. and Carmack, E. C.: Deepening of the nutricline and chlorophyll maximum in the Canada Basin interior, 2003-2009, Geophys. Res. Lett., 37, L24602, doi:10.1029/2010GL045459, 2010.

McManus, D. A., Kelley, J. C., and Creager, J. S.: Continental shelf sedimentation in an Arctic environment, Geol. Soc. Am. Bull., 80, 1961-1984, 1969.

McRoy, C. P.: ISHTAR, the project: an overview of inner shelf transfer and recycling in the Bering and Chukchi seas, Cont. Shelf Res., 13, 473-479, 1993.

Moran, S. B., Kelly, R. P., Hagstrom, K., Smith, J. N., Grebmeier, J. M., Cooper, L. W., Cota, G. F., Walsh, J. J., Bates, N. R., Hansell, D. A., Maslowski, W., Nelson, R. P., and Mulsow, S.: Seasonal changes in POC export flux in the Chukchi Sea and implications for water column-benthic coupling in Arctic shelves, Deep-Sea Res. Pt. II, 52, 3324-3343, 2005.

Nishino, S.: R/V Mirai Cruise Report MR13-06. JAMSTEC, Yokosuka, Japan, available at: www.godac.jamstec.go.jp/darwin/ datatree/e (last access: 25 September 2015), 2013.

Nishino, S., Kikuchi, T., Yamamoto-Kawai, M., Kawaguchi, Y., Hirawake, T., and Itoh, M.: Enhancement/reduction of biological pump depends on ocean circulation in the sea-ice reduction regions of the Arctic Ocean, J. Oceanogr., 67, 305-314, doi:10.1007/s10872-011-0030-7, 2011.

Nishino, S., Itoh, M., Williams, W. J., and Semiletov, I.: Shoaling of the nutricline with an increase in near-freezing temperature water in the Makarov Basin, J. Geophys. Res.-Oceans, 118, 635-649, doi:10.1029/2012JC008234, 2013.

Nishino, S., Kawaguchi, Y., Inoue, J., Hirawake, T., Fujiwara, A., Futsuki, R., Onodera, J., and Aoyama, M.: Nutrient supply and biological response to wind-induced mixing, inertial motion, internal waves, and currents in the northern Chukchi Sea, J. Geophys. Res.-Oceans, 120, 1975-1992, doi:10.1002/2014JC010407, 2015.

Pabi, S., van Dijken, G. L., and Arrigo, K. R.: Primary production in the Arctic Ocean, 1998-2006, J. Geophys. Res., 113, C08005, doi:10.1029/2007JC004578, 2008.

Rainville, L. and Woodgate, R. A.: Observations of internal wave generation in the seasonally ice-free Arctic, Geophys. Res. Lett., 36, L23604, doi:10.1029/2009GL041291, 2009.

Redfield, A. C., Ketchum, B. H., and Richards, F. A.: The influence of organisms on the composition of seawater, in: The Sea Vol. 2, edited by: Hill, M. N., Wiley, New York, USA, 26-77, 1963.

Sato, K., Aoyama, M., and Becker, S.: Reference materials for nutrients in seawater as calibration standard solution to keep compa- 
rability for several cruises in the world ocean in 2000s, in: Comparability of Nutrients in the World's Ocean, edited by: Aoyama, M., Dickson, A. G., Hydes, D. J., Murata, A., Oh, J. R., Roose, P., and Woodward E. M. S., Mother Tank, Tsukuba, Japan, 43-56, 2010.

Schlitzer, R.: Ocean Data View. Alfred Wegener Institute, Bremerhaven, Germany, available at: http://odv.awi.de, last access: 25 September 2015.

Springer, A. M. and McRoy, C. P.: The paradox of pelagic food webs in the northern Bering Sea-III. Patterns of primary productivity, Cont. Shelf Res., 13, 575-599, 1993.

Stroeve, J., Holland, M. M., Meier, W., Scambos, T., and Serreze, M.: Arctic sea ice decline: Faster than forecast, Geophys. Res. Lett., 34, L09501, doi:10.1029/2007GL029703, 2007.

Walsh, J. J., McRoy, C. P., Coachman, L. K., Goering, J. J., Nihoul, J. J., Whitledge, T. E., Blackburn, T. H., Parker, P. L., Wirick, C. D., Shuert, P. G., Grebmeier, J. M., Springer, A. M., Tripp, R. D., Hansell, D. A., Djenidi, S., Deleersnijder, E., Henriksen, K., Lund, B. A., Anderson, P., Müller-Karger, F. E., and Dean, K.: Carbon and nitrogen cycling within the Bering/Chukchi Seas: Source regions for organic matter effecting AOU demands of the Arctic Ocean, Prog. Oceanogr., 22, 277-359, 1989.

Weingartner, T. J., Cavalieri, D. J., Aagaard, K., and Sasaki, Y.: Circulation, dense water formation, and outflow on the northeast Chukchi shelf, J. Geophys. Res., 103, 7647-7661, doi:10.1029/98JC00374, 1998.

Weingartner, T. J., Danielson, S., Sasaki, Y., Pavlov, V., and Kulakov, M.: The Siberian Coastal Current: A wind- and buoyancyforced Arctic coastal current, J. Geophys. Res., 104, 2969729713, doi:10.1029/1999JC900161, 1999.

Welschmeyer, N. A.: Fluorometric analysis of chlorophyll $a$ in the presence of chlorophyll $b$ and pheopigments, Limnol. Oceanogr., 39, 1985-1992, 1994.
Yamada, Y., Fukuda, H., Uchimiya, M., Motegi, C., Nishino, S., Kikuchi, T., and Nagata, T.: Localized accumulation and a shelfbasin gradient of particles in the Chukchi Sea and Canada Basin, western Arctic, J. Geophys. Res.-Oceans, 120, 46384653, doi:10.1002/2015JC010794, 2015.

Yamamoto-Kawai, M., Tanaka, N., and Pivovarov, S.: Freshwater and brine behaviors in the Arctic Ocean deduced from historical data of $\delta^{18} \mathrm{O}$ and alkalinity (1929-2002 A.D.), J. Geophys. Res., 110, C10003, doi:10.1029/2004JC002793, 2005.

Yamamoto-Kawai, M., McLaughlin, F. A., Carmack, E. C., Nishino, S., Shimada, K., and Kurita, N.: Surface freshening of the Canada Basin, 2003-2007: River runoff versus sea ice meltwater, J. Geophys. Res., 114, C00A05, doi:10.1029/2008JC005000, 2009.

Yao, W. and Byrne, R. H.: Simplified seawater alkalinity analysis: Use of linear array spectrometers, Deep-Sea Res. Pt. I, 45, 1383 1392, 1998.

Yokoi, N., Matsuno, K., Ichinomiya, M., Yamaguchi, A., Nishino, S., Onodera, J., Inoue, J., and Kikuchi, T.: Short-term changes in a microplankton community in the Chukchi Sea during autumn: consequences of a strong wind event, Biogeosciences, 13, 913923, doi:10.5194/bg-13-913-2016, 2016.

Yun, M. S., Whitledge, T. E., Kong, M., and Lee, S. H.: Low primary production in the Chukchi Sea shelf, 2009, Cont. Shelf Res., 76, 1-11, doi:10.1016/j.csr.2014.01.001, 2014.

Yun, M. S., Whitledge, T. E., Stockwell, D., Son, S. H., Lee, J. H., Park, J. W., Lee, D. B., Park, J., and Lee, S. H.: Primary production in the Chukchi Sea with potential effects of freshwater content, Biogeosciences, 13, 737-749, doi:10.5194/bg-13-7372016, 2016. 